\title{
Revealing the Silenced Spots: The Influence of Thomas and Znaniecki on the Study of Marginalized Aspects of Social Life*
}

\author{
Anna Kacperczyk \\ University of Lodz, Poland
}

DOI: http://dx.doi.org/10.18778/1733-8077.16.4.13

\section{Keywords:}

William I. Thomas;

Florian F. Znaniecki;

Jakub Wojciechowski;

Władek Wiśniewski;

Humanistic

Coefficient;

Polish Peasant;

Literacy; Polish

Memoirism; Memoir

Competitions;

Peasants and

Working-Class's

Voice; Silencing

Practices

\begin{abstract}
This article aims to highlight the influence of the work of William I. Thomas and Florian Znaniecki on the perception of social reality by sociologists. I focus on the social practice of creating personal documents (memoirs, autobiographies, and letters) as a form of enacting individual agency and speaking their voice in the social space. I show the contribution of various social classes in this memorializing practice in Poland, reaching back to the $17^{\text {th }}$ and $18^{\text {th }}$ centuries. While doing so, I emphasize that a big part of society was practically muted in literary discourses. The voices of peasants and working-class were silenced as they had no access to the means which would enable them to speak and be represented in the discourse. Against this background, we can see how the "memoir competitions"-a very popular research practice being introduced in Poland by Znaniecki in 1921-have changed the power relations in the field of generating knowledge about social reality. The institution of Polish Memoirism that systematically gathered a huge number of autobiographies, enabled the poor and voiceless to speak and be heard by social researchers. In this sense, the monumental work of Thomas and Znaniecki was a trigger to the gradual process of revealing "blind spots" on the map of social reality and giving voice to the muted. Throughout the article, I return again and again to the main methodological questions, that is, what does it mean to include the consciousness of the participants of social life in sociological research, how to represent them in sociological theorizing, and how they can regain their voice in the scientific narrations about them.
\end{abstract}

Anna Kacperczyk is an Associate Professor of sociology at the University of Lodz, Poland. Substantive areas of her research included palliative and hospice care in Poland (2006), the sustainable development of an Amazonian village (2013), the social world of climbing (2016), and trash (in press). She is interested in the theory of social worlds, the methodology of social research, especially the issue of the position and role of the researcher in the investigation process. In her field research, she refers to the theoretical framework of symbol- ic interactionism, using ethnography, autoethnography, and methodology of grounded theory. She is a chairperson of the Section of Qualitative Sociology and Symbolic Interactionism of the Polish Sociological Association and a member of the board of European Society for the Study of Symbolic Interaction. She serves as an associate editor and cover designer of the Qualitative Sociology Review.

email address: anna.kacperczyk@uni.lodz.pl 
We take up our job with the belief that in the world of human actions, just like in nature, nothing is lost.

[Florian Znaniecki 1911] ${ }^{1}$

\section{Polish Peasant in Europe
and America (Thomas and
Znaniecki 1918-1920), one
of the most influential}

monographs in sociology, is a multidimensional and dense work that can be studied in many different ways. Reading this monumental study, one can still discover new threads and dimensions of the analysis. In this article, I focus on the influence of the work of William I. Thomas and Florian Znaniecki on the domain of sociological investigations, which provided sociology with "a new direction of the attention" (Thomas 1905:445). ${ }^{2}$ I am especially interested in their then groundbreaking approach that linked the theory construction with in-depth empirical research, and particularly the idea of taking into account human consciousness as an indispensable element in establishing and understanding social reality. Additionally, I take up the methodological thread of what it means to take into account the consciousness of the participants of social life being studied and to what extent the authors have succeeded to do so.

I thus offer a journey through the social reality that Thomas and Znaniecki attempted to explain

\footnotetext{
*This article is based on the keynote speech given by the author at the International Conference "The Polish Peasant in Europe and America 1918-1920" held in Salerno (October 30-31, 2019, see: Cersosimo 2020).

1 The sentence expressed by Znaniecki in the first issue of "Wychodźca Polski [Polish Emigrant]" cited for Dulczewski (1992:77).

${ }^{2}$ I refer here to the sentence expressed by William I. Thomas (1905:455): "But, after all, there is but one reality, and a new science never represented anything more than a new direction of the attention."
}

by referring to the peasants' experiences. And by so doing, I show the power relations in Polish society-being the source of peasants' voices. This journey attests to the uniqueness of the approach of the authors of The Polish Peasant, but, at the same time, illuminates its shortcomings, hard to avoid at that time.

Another layer of my considerations is tracing the mass gathering of life records launched by Znaniec$\mathrm{ki}$ as a response to the need for reaching the minds of the individuals under study. Showing the extraordinary career of mass memoirism in Poland, I will juxtapose the ideas of The Polish Peasant with the results of those collective activities-again asking about the agency and representation of the silenced parts of the society in the literary discourse.

As Thomas argued: "the individual mind cannot be understood apart from the social environment and...a society cannot be understood apart from the operation of the individual mind" (Thomas 1905:445). In his work, Introduction to Sociology, Znaniecki (1922) emphasized that the fundamental property of cultural phenomena is that, as being objects of theoretical reflection of the researcher, they already are the objects of their individual experiences, their conscious actions (Znaniecki [1922] 1988:25). The observed phenomena are objects of human consciousness, and we should study them thusly. If we wish to understand social reality, we should consider the meanings and interpretations of the situations constructed and employed by the individuals, their definitions of the situations (Thomas and Znaniecki 1918, vol. I.:68). Outlining the role of the social researcher, both authors state:

We must put ourselves in the position of the subject who tries to find his way in this world, and we must 
remember, first of all, that the environment by which he is influenced and to which he adapts himself, is his world, not the objective world of science-is nature and society as he sees them, not as the scientist sees them. [Thomas and Znaniecki 1919:20-21]

This means that any social phenomenon depends on the subjective standpoints taken by individuals "toward this phenomenon and can be calculated only if we know not only the objective content of the assumed cause, but also the meaning which it has at the given moment for the given conscious being" (Thomas and Znaniecki 1918, vol. 1:38). In another part of The Polish Peasant the authors state:

The individual subject reacts only to his experience, and his experience is not everything that an absolutely objective observer might find in the portion of the world within the individual's reach, but only what the individual himself finds. And what he finds depends upon his practical attitudes toward his environments, the demands he makes upon it and his control over it, the wishes he seeks to satisfy and the way in which he tries to satisfy them. [Thomas and Znaniecki 1919:20-21]

Afterward, Znaniecki will name this epistemological principle humanistic coefficient, explaining that social researchers as the "inductive student of culture" should approach the empirical data, including how they are perceived, experienced, and used by the studied individuals.

In contrast with the natural scientist, who seeks to discover an order among empirical data entirely independent of conscious human agents, the student of culture seeks to discover any order among empirical data which depends upon conscious human agents, is produced, and is maintained by them. To perform this task he takes every empirical datum which he investigates with what we have called its humanistic coefficient, i.e., as it appears to those human individuals who experience it and use it. [Znaniecki 1963:132]

Thomas and Znaniecki attempted to meet this challenge by referring to personal documents. They assumed that "personal life-records, as complete as possible, constitute the perfect type of sociological material" (Thomas and Znaniecki 1919:6). For them, the human experiences and attitudes are "data and elementary facts which are not exclusively limited to this individual's personality, but can be treated as mere instances of more or less general classes of data or facts, and can thus be used for the determination of laws of social becoming" (Thomas and Znaniecki 1919:7).

It was Thomas who first expressed a need for the use of, as he named them, undesigned records, ${ }^{3}$ like "letters, diaries, newspapers, court, church, and club records, sermons, addresses, school curricula, and even handbills and almanacs" (Thomas 1912:771772). In 1912, he already projected the research methods using immigrants' letters: "The letters, for instance, of the immigrant to his home people, and theirs to him, reveal life and mind in a very intimate way" (Thomas 1912:772). In his Masters of Sociological Thought, Lewis A. Coser observes that Thomas came up with the idea of using letters by accident. Initially, during his study on Polish immigrants, based on observations, he even tried to learn Polish, as part of ethnographical methods developed and typically applied in studies of nonliterate peoples at that time. At that moment, he did not yet think of gathering written information (Coser 1977:533).

\footnotetext{
3 Characterizing materials and research methods for the interpretation of the mental life of a race, Thomas indicated three principal forms of data gathering: personal observation, undesigned records, and designed records (Thomas 1912:770).
} 
After deciding to concentrate his study on the Polish community, Thomas, befitting his ethnographical training and following, established procedures among anthropologists who mastered the Polish language. He then set out to develop extensive contacts with the Polish community in Chicago, as well as to take field trips to Poland. At that point, Thomas still used methods that had been developed in studies of nonliterate peoples and did not yet think of gathering written information.

One rainy morning, while walking down the back alley behind his house, Thomas had to side-step to avoid a bag of garbage which someone was throwing from the window. As the bag burst open at his feet, a long letter fell out. He picked it up, took it home, and discovered that it was written in Polish by a girl taking a training course in hospital. It was addressed to her father and mainly discussed family affairs and discords. It then occurred to Thomas that one could learn a great deal from such letters. This was the unlikely incident that led to Thomas's development of the life-history method for which he has since become famous. [Coser 1977:533]

True or not, this picturesque vision still enlivens the sociological imagination and nourishes it as a "methodological legend" with the historical view of a quest for science on the social reality that would rely on humanistic explorations. Thomas, indeed, initiated gathering the letters of Polish immigrants from 1909-1910, which was immediately after obtaining the funds from Helen Culver to the sum of 50.000 USD. He encouraged the Poles through Polish newspapers "to hand in their letters from family members in Poland and offered 10-20 cents for every letter" (Dulczewski 1992:103). A few years later, this source of data was successfully applied in The Polish Peasant. The set of 764 letters (dated 1893-1914) was an entirely new type of research material in sociological research. ${ }^{4}$ These letters ${ }^{5}$ gave way to the communication reality of Polish peasants who were at a distance. And yet, being far away from home, they wanted to keep in touch, settle various matters, solve practical problems, and still be an active element of the world they came from, or at least be in touch with it. This rich collection of peasants' letters gathered for longer periods was ordered in a family series and meticulously described and commented on by the authors.

Besides this epistolary material, the attitudes and behaviors of Polish peasants were described based on: court reports, folk culture descriptions in the literature, correspondents' letters written for Polish newspapers, entries in parish documents, chronicles of Polish-American societies, protocols of various social institutions and agencies set up to deal with social problems such as crime, alcoholism, and difficulties in adapting, and, of course, autobiographical accounts, including the famous life record of an immigrant-Władek Wiśniewski. ${ }^{6}$

Personal documents (diaries, autobiographies, memoirs, letters) can become a source material in sociological research in two ways. First, when one handles those as extant data, already existing in social reality, created regardless of the researcher's activity, as it was in the case of immigrants' letters.

\footnotetext{
${ }^{4}$ In his work The Condition of the Working Class in England published in 1845, Friedrich Engels also used workers' letters and documents from various institutions. However, his work does not constitute a theoretical, but rather an ideological account of the circumstances of working-class life.

${ }^{5}$ The letters were mainly obtained from the archives of the Cracow newspaper Gazeta Świateczna [Festal Newspaper] and readers of the emigrant Dziennik zwiazkowy [The Union Journal]. ${ }^{6}$ In Polish literature, the author of the famous personal life-record is recalled as Władek Wiśniewski. I keep this Polish spelling here, although in the original work of Thomas and Znaniecki (1919:82) his name is spelled Władek Wiszniewski.
} 
The second way is to elicit those, to make them happen, which assumes asking people and making them create such documents. The memoir of an immigrant, Władek Wiśniewski, presented in the third volume of The Polish Peasant (Thomas and Znaniecki 1919), is an extensive example of autobiographical material of the second type, eagerly gathered by the social researchers. Polish sociology has a long tradition in that respect. The first one who introduced the organized collecting of such kinds of sources and practicing empirical research referring to them was Florian Znaniecki.

\section{The Memoir Competitions in Poland}

In 1919, when Poland regained independence, Znaniecki was offered to chair the Department of Philosophy at the newly organized University in Poznan. He accepted the Chair and, in 1920, renamed it into the Department of Sociology and Philosophy of Culture. The same name was given to his sociological seminar. Znaniecki brought to Poland the idea of gathering and elaborating sociological materials and founded "a school of theoretic and applied sociology" (Dulczewski 1992:140). From the very beginning of his work in Poznan, it was clear that Znaniecki was interested in the autobiographical method. He also demanded that the participants of his seminar "write their own life history. He justified this, asserting that people who intend to do researches upon the lives of other people should show the ability of reflection about their own way of life" (Dulczewski 1992:143).

\footnotetext{
${ }^{7}$ Znaniecki also wrote an autobiography, which was published anonymously in 1920 as an article "Intellectual America" in The Atlantic Monthly. He created this life record during a research program carried out with William I. Thomas for Carnegie Corporation. The theme of the research was the Americanization of various immigrant groups settled in the U.S. In this autobiography, Znaniecki expressed opinions about his own "Americanization," giving an example of a special category-"Amer-
}

Thus, immediately after returning to Poland, Znaniecki implemented the idea that emerged from his collaboration with Thomas. His first move towards adding to the knowledge about contemporary society was the very announcement of a competition for memoirs. The first memoir contest announced by Znaniecki in 1921 was addressed to physical workers. Interested in the situation of life conditions of the urban and rural proletariat, Znaniecki elaborated a comprehensive program of research in which he indicated issues to be investigated and methods to be applied (Dulczewski 1992:151; see also: Dulczewski 1975; Wincławski 2012). The central theme of this study was the working class's conditions of life. The precise terms of participation were detailed in the contest announcement:

The Sociological Institute in Poznan, wishing to study the social conditions of working in Poland, announces a competition for the best biography of an employee, written by himself.

First prize: 100,000 (one hundred thousand), Second prize: 50,000 (fifty thousand).

The Institute will pay from 2,000 to 6,000 marks for unawarded resumes, depending on their volume, as a form of reimbursement. Everyone who makes a living by physical work can participate in the competition: workers in factories, mines, industrial plants, city workers, farmworkers, railway workers, craftsmen of all professions. Supervisors and work managers can participate in the competition if they have once worked in physical labor themselves. This is a great opportunity for all those who are temporarily out of work. A biography must have at least 600 pages, the size of a regular quarter of paper; the more

icanization of intellectualists" (Dulczewski 1992:126-127). The results of this research were published in the book Old World Traits Transplanted (1921) signed with the names of Herbert A. Miller and Robert E. Park. 
pages, the more likely the reward. Whoever cannot write, may dictate to someone else. Grammatical errors, incorrect style, poor penmanship do not interfere with getting the prize. You should not think that writing a story of your own life is very difficult. One of the best autobiographies worldwide was written by a Pole-a tramp, a bakery journeyman. The only thing is to describe honestly, truthfully, and in detail your whole life from childhood to the present. [a fragment of the competition appeal; Polish Sociological Institute in Poznan, 1921; Chałasiński (1931) 1979:68 (trans. AK)]

There have been cash prizes planned, and illiteracy of a diarist was not an obstacle to participate in the contest since people who did not know how to write were able to "dictate to someone else. Grammatical errors, incorrect style, poor penmanship do not interfere with getting the prize." There were also rules established to anonymize the participants. This first memoir competition addressed to the working class brought 149 autobiographies. Additionally, the organizers received 70 workers' life histories that were assessed as a material of low sociological value, which consisted of very short several-page resumes. The effects of the contest are two published biographies of workers-of Jakub Wojciechowski (1930), who was the winner of the competition, and of honorable mention Władysław Berkan (1923). Also, a monograph based on gathered materials was written by Znaniecki's student and collaborator, Józef Chałasiński (1931), The Paths of Social Promotion of the Worker.

\section{The First Winner: Jakub Wojciechowski}

The winner of the first autobiographical contest, Jakub Wojciechowski (1884-1958), was a son of landless illiterate workers from a very poor family. He attended school up to the age of 14, at the same time making a living as a shepherd or doing other works. At the age of 15, he immigrated for work to Germany and returned to Poland after 25 years of living abroad. When writing a memoir, he was an ordinary worker, 37 years old.

The Worker's Biography, edited by Józef Chałasiński and published in 1930, aroused the admiration of literary critics in Poland. The work was fine enough to impress famous Polish writer, poet, and critic, Tadeusz Boy-Żeleński, who was entranced with the memoir and became the promoter of its author, referring to Wojciechowski "a Polish classic in a worker's sweatshirt." 8 The publisher intentionally preserved the original wording used by the author, his peasant dialect "sounds" in the stream of words, in meticulous descriptions of the scenes, conversations, and interactions. On 443 pages of the manuscript, Wojciechowski depicted his life in detail, with dense reconstructions of events, contexts, interactional situations. The material is valuable in a historical, sociological, and biographical sense, giving deep insight into the life and experience of a country boy. Despite the distinct dialect language, the readers know for sure that they are dealing with an autobiography in its best form. ${ }^{9}$

The fate of the narrator was featured by randomness, dependence on external events, factors, and other people. Very often, the trajectory of his life hinged on somebody's arbitrary choice, which was evident in the scene of deciding whether to send Jakub to school. As a young boy, Jakub eagerly ex-

\footnotetext{
${ }^{8}$ After winning the first prize, Jakub Wojciechowski was appointed a member of the Polish Academy of Literature, introduced to the representatives of the highest state authorities, and-due to his cordial promoter, Tadeusz Boy-Żeleński-was included in intellectual circles.

${ }^{9}$ See also: Pietraszek 1985; Kwilecki 2011.
} 
pected to attend classes. He visited the neighboring village to see what the school was like. He asked his mother many times when he would finally go to school, and she pointed out to him the successive events in the agricultural calendar: when a goat delivers her babies, when we bring the Easter basket to the church, when the storks arrive. And, when it was finally the time for Jakub to start education, his father brought a message from his employer, who was persuading Jakub's parents to not send the boy to school yet. "You know, Jagna, what Piasecki said, that we are not supposed to send our Jakub to school this year" (Wojciechowski [1930] 1971:39). Jakub began to cry, he even threatened his parents that he would run away from home. But, it did not help. His father argued that Jakub could look after his younger siblings, and due to that his mother would go to work for Mr. Piasecki and earn some money (30 pfennigs a day). At first, the mother did not agree with that. In her first instinctive reaction, "she started scolding father that we are such oxen that we must ask everyone to write us a letter. Is it supposed to be the same for our children, so that they would have to ask someone to write a letter on their behalf? Jakub will go to school and that will be the end" (Wojciechowski [1930] 1971:39). When the father informed his employer that he could not reach an agreement with his wife and that Jakub was about to go to school, Mr. Piasecki started to interfere and to visit them at home. "And after lunch, this employer came to my mother, confused my mother's head so much that my mother let herself be persuaded to do so. And he said that my mother could go to work in the afternoon and earn nine 'trojak' [Polish money] for a week, but if she would send me to school, she would have such a loss that my mother let herself be persuaded" (Wojciechowski [1930] 1971:39). Further peripeteia included the father's attempt to obtain a medical certificate from a doctor that the child was unfit for school. The first doctor throws the father away, yelling at him that the child is healthy and should go to school. But, then Mr. Piasecki intervenes again. He talks to the doctor privately, perhaps bribing him, and finally, the doctor agrees to write out a false certificate of Jakub's inability to attend school.

This is just one example of the hundreds of mini-stories described by Wojciechowski in his dense and rich autobiography. What is striking here is that the child's fate and his opportunities were decided by a stranger, who felt entitled to interfere in decisions concerning the education of his subordinate's child. In this way, not only he had access to the energy of his employees, but their time, resources, and even the future of their relatives were also at his disposal. The mother was aware that their illiteracy condemns their family members to be perpetual "work oxen," to perform the hardest physical work, the inability to be socially promoted and independent in handling their affairs (always in need of asking others for help in reading and writing a letter).

Let us imagine a farm worker who does not know how to read and write, who is attached to the manor, perhaps not so much legally, yet, in fact, through his illiteracy, burdened with a large family, the lack of entrepreneurship, and helplessness in life...Suppose, moreover, that such a laborer has such bearable conditions that he does not starve and may get drunk from time to time. How will his social consciousness develop? His most important feature will be a submissive attitude. [Chałasiński (1931) 1979:53 (trans. AK)]

The content of the memoir of Jakub Wojciechowski may be shocking to the present-day reader. One can see the everyday struggle of the poor to survive there, to get some food, to have a shelter, to secure 
the very basic life needs in the situation of severe social inequality. Until 1900, the farmworkers were subject to corporal punishment. ${ }^{10}$

It is essential to observe that this memoir was written from the position of a person coming from a lower social class, whose promotion and social advance depended mainly on the possibility of participating in culture and the ability to use the written word (see: Freire and Macedo 2005). It was a person for whom the peasant world was a natural life world, and who created a peasant story. This life history was written from a particular position-necessarily different than created in memoirs of manor houses that reproduced the culture of higher social classes. Therefore, this was the exceptional record that enacted the voice of peasant society. And this voice could be heard due to the unique interest of Polish sociologists in the autobiographies of peasants and the working class. In this way, voices of the lower class were allowed to become part of "people's history" of Polish society.

\section{The Memorializing Practices}

If we go back in time, we would see that in Poland, but also other countries, only some part of society was literate, could read and write. ${ }^{11}$ And for this rea-

\footnotetext{
10 "An industrial worker who has been insulted or hit has the right to quit his job immediately. Until 1900, a farmworker was still subject to corporal punishment by his employer. Only the new civil law abolishes this barbaric law, but even now, the [rural] worker who has been beaten has no right to quit his service immediately" (Marchlewski 1903:268).

${ }_{11}$ There were some exceptions, for instance, Iceland, where peasants were literate a few centuries back from now and thus could save their family histories. At the beginning of the $18^{\text {th }}$ century, a large part of the Icelandic population could read, "and this had probably been more or less the case from the close of the twelfth century. Even at this early date...nearly all chieftains and better-off farmers could both read and write" (Tomasson 1975:67). Additionally, "in 1744, religious training was made mandatory for all youth, and...the pastors were ordered
}

son, illiterate parts of society were excluded from the memorializing activities. Creating memoirs was always a part of cultural practices that encouraged participants of a given milieu to preserve some objects or memories for future generations and to share stories. People who create these kinds of notes or transcripts must have access to the specific technology of "making such records," know how, and for what reason to perform it. In Poland, there exist extensive archives of memoirs created by the representatives of the nobility and clergy - the ones who had access to know-how and were able to record the traces of their lives, thoughts, and memories. The gentry wrote memoirs not challenged by anyone, out of their own need and under the prevailing custom. Having time, means, writing materials, and, above all, the skills acquired in the education process they received at home, they treated this form of narrative expression as a form of communication suitable for literate and educated people.

Today, we understand the memoir as "a literary work describing the author's fate and internal experiences, as well as the events in which he participated, witnessed, or heard about" (Cieński 1981:9 [trans. AK]). However, this genre is not evident. Even though the term memoir means notes taken from a certain perspective of time, many old Polish documentarians conducted diary reports regularly, describing what happened on a specific date, making memoirs a utilitarian, not literary form, and those serving reporting or information purposes (e.g., during missions, war campaigns, various types of ceremonies, or

to make regular visits to all homes in their parishes to ensure that this training was properly carried out. The legislation also contained a provision stating that illiterate parents, whenever they had the necessary means, must engage someone in their place to teach children to read." In effect, as the study of parish registers shows, in the period 1780-1790, near-universal literacy was achieved in Iceland (Tomasson 1975:68). 
parliaments). ${ }^{12}$ Also, travelers usually kept diaries, presenting what they saw and whom they met on a given day. Among the nobility, such notes commemorating the events considered by the author to be valid were popular and can be easily found.

It is interesting that in the old-time Polish language, till the mid- $18^{\text {th }}$ century, the "memoir" was understood as "a man who remembers a lot" (Cieński 1981:8 [trans. AK]). And, what made this term even more blurry, was some shift in its meaning in the age of Enlightenment that brought the idea of memoir as something material. A "memoir" was "a specific object that remembers an event...Then the 'memoir' begins to be semantically identified with the former word 'souvenir'-as 'a piece to commemorate an event or person'"' (Cieński 1981:8 [trans. AK]). Thus, the Enlightenment memoir was a material thing: "a monument, a memorial tree, a building, a specific place in the area, finally, some pictures, some numismatic item, some trinket. This is something that needs to be embedded in a particular spatially specific place," or "a collection of material things" (Cieński 1981:10-11 [trans. AK]). ${ }^{13}$ However, "according to the universal postulate of utility, the souvenir should be decorative, functional, and economical

\footnotetext{
${ }^{12}$ In his Bibliography of Polish and Concerning Poland Memoirs (1928), Edward Maliszewski mentions Janko of Czarnkow (ca. 1320-1387) as the first Polish diarist, a chronicler and diplomat in the service of Polish bishop and later Deputy Chancellor of the Crown and Archdeacon of Gniezno. In 1377-1386, Janko wrote a chronicle about the years 1370-1384, based on the events he witnessed.

${ }^{13}$ This conception originates from the philosophical views of the era of Enlightenment, which operated in the "antinomy between the shortness and ephemerality of the human's life and the desire to 'survive' longer than an individual life, to secure secular immortality by placing oneself permanently in the memory of the human species, which is immortal and everlasting" (Holbach as cited in Cieński 1981:10 [trans. AK]). To commemorate oneself, significant others, or relevant events, material objects were used with full confidence to their permanence as a part of the order of the physical world they represented.
}

in addition to its commemorative function. Such souvenirs were: magnate mansions, family parks and gardens (Sofiowka, Pulawy, Tulczyn, Powazki), galleries of family portraits" (Cieński 1981:11 [trans. $\mathrm{AK}])$. One can easily see that accumulation of the capital allowed the noble and aristocracy, and even the bourgeoisie, to leave some permanent material traces of their lives and activities.

Whereas the genre of "memoir text," that is of our interest here, includes records that varied in formal terms: from autobiography, reminiscences, diary, memories, chronicles, through intimate journals, to epistolographic accounts (Cieński 1975:18). Letters or their entire collections constituted a separate category of texts containing the personal reference. But, even those fell into the category of "hybrid writings"-formally being a collection of correspondence written "with a clear, fully conscious purpose of making them a memory source for future generations" (Maliszewski 1928:viii [trans. AK]). ${ }^{14}$

A Polish literary scholar, Alojzy Sajkowski (1964), sees the primary aboriginal links of memoirs in rough records named "raptularze"15 and "memoir books" (ksieggi pamiętnicze) written by the gentry for mostly

\footnotetext{
${ }^{14}$ For example, Letters from a Journey by A. E. Odyniec or Letters by A. E. Koźmian (Maliszewski 1928:viii). Moreover, handwritten memoirs may intersect with numerous varieties of travel journalism, like: letter account, regular and irregular diary, memoir, or travel poem (Sajkowski 1964). Andrzej Cieński (1975:18) asserts that practically in every epoch, apart from "explicit" and "proper" memoirs, there were numerous hybrid texts, which, however, represent-recalling the term of Anna Robeson Burr (1909) - "an autobiographical intention," the essence of which is the individual's accountability to oneself and the world.

${ }^{15}$ The name "raptularz" came from Latin rapere, which means to seize, take, or snatch. In old Polish culture, it was a kind of a housekeeping book, in which events from the family life or gossips from the neighborhood, notes on social ceremonies and events, jokes, public affairs, anecdotes, expenditures, prices of commodities were randomly written down (Sajkowski 1964:33-34).
} 
private and family use. In Polish culture, rich sources of such records from the $16^{\text {th }}$ and $17^{\text {th }}$ centuries arose and have been accumulated in libraries and private collections. ${ }^{16}$ Especially the $17^{\text {th }}$ century was a time of the lively development of memoirs. "This change was caused...by the rapid increase in the literacy of the gentry, which, starting from the second half of the $16^{\text {th }}$ century, began massively gaining the education and, as a consequence, writing down memories of their lives" (Krzywy 2012 [trans. AK]).

In Poland, the tradition of writing diaries and memoirs was strong and widespread (Cieński 1981:35). How many of them have been created? In his comprehensive Bibliography of Polish and Concerning Poland Memoirs, Edward Maliszewski (1928:ix) lists 5,445 items (4,465 prints and 966 manuscripts plus some supplements) covering the period from 1370 to 1928 . There is no doubt that those memoir archives were mainly the source of the collective self-knowledge of the nobility. ${ }^{17}$

\section{The Silenced Parts of the Society}

In contrast to the nobility, the peasantry has not left any material "souvenirs." All human energy of this

\footnotetext{
${ }^{16}$ The most famous are the memoirs of Jan Chryzostom Pasek (1836) whose writings provide an excellent example of Polish Baroque prose (Rytel 1962).

${ }_{17}$ Maliszewski reported that he drew information on handwritten diaries mostly from the printed catalogs of larger Polish libraries. At that time the National Library already had a rich collection of memoirs consisting of three big complexes: old Rapperswil collections; extensive collections left by J. Kraszewski, purchased from the family of the writer, and manuscripts from the former Załuski Library, which have been regained from Russia, and temporarily stored in the University Library in Warsaw. Also, he examined the manuscript collections of the libraries of Krasiński, Przeździecki, Zamoyski, and the manuscript sections of several private collectors. Courtesy of Mr. Stanisław Piotr Koczorowski, he also provided a list of diaries from the collection of the Polish Library in Paris (Maliszewski 1928:ix). Those materials from the entire collection belonged to the nobility, were created by them, and stored in their libraries.
}

social class fueled the survival, the maintenance of life. In 1900, peasants constituted almost $75 \%$ of the population of Poland (Łepkowski 1973:630). Despite their number, they were a non-privileged social class, whose rights were gradually taken away from them over centuries.

Although until the $10^{\text {th }}$ century, free peasants made up the majority of the Polish population, during the $11^{\text {th }}$ and $12^{\text {th }}$ centuries, most of them lost their freedom and fell into feudal dependence. The ownership of the land they cultivated passed into the hands of the feudal lords, and therefore they were obliged to pay a feudal rent in labor, grain, and other products. Additionally, the peasants were burdened with tributes and services to the king or prince, and tithing to the church. Over the centuries, the peasants became increasingly poor and dependent on their lords (prince, church, nobles). Around the $14^{\text {th }}$ and $15^{\text {th }}$ centuries, their right to leave the land became restricted. Besides the right to migrate, peasants also lost the rights to own land and judicial recourse towards their feudal lords (Bardach, Leśnodorski, and Pietrzak 1987:98-99).

The burdensomeness of serfdom was unquestionable. Historians emphasize that the oppression resulted in numerous cases of escapes of peasants as a form of resistance (Śreniowski [1948] 1997:39; Rauszer 2020:59-60)..$^{18}$ It is worth mentioning that many voices lamenting over the captivity of peas-

\footnotetext{
${ }^{18}$ Michał Rauszer (2020:45-49) listed various forms of peasant resistance resorted to daily in the course of serfdom slave labor: sabotaging work, laziness, pretending to be stupid, the spectacles of humility (bowing and taking off the hat in front of a lord in humble prostrations), stealing lord's property, poaching, working with faulty tools to justify wasting time on repairing broken equipment (not to work). Since open revolts constituted a suicide act for the peasant and flight was not always possible, the peasants used these forms of hidden implicit defiance in everyday life.
} 
ants or terrible living conditions of the working class came from activists and political writers of the $18^{\text {th }}$ century (Konopczyński 1966). ${ }^{19}$ In his Anatomy of the Republic of Poland, Stefan Garczyński (1751) deplores Polish poverty and backwardness, stating that:

The lord does not regret the resting of the tired hunting dogs, but he does regret it for the serf workers. Dirt, sloppiness reigns in the countryside, for who can desire a profit, savings, neatness, when even what he has collected, his master can always dispose of! 271 days of free serfdom, sometimes three people; when the peasant will go to church and how people are to respect holidays if it is not possible to go to the market on weekdays. [Konopczyński 1966:147 (trans. AK)] ${ }^{20}$

Another political writer, Antoni Wiśniewski (176062), asked:

Is it compatible with humanity that every particular lord of the manor should be the lord of human life and death? And the whole poor household of his subject? That the subject should have nothing of his own, nothing certain? To take everything from him and squeeze him out of tribute? To take from him almost all or most of the days of the week and of the year [making it impossible] to work for his children, and home, and food? That it would not be allowed to change the place and the lord in the greatest oppression and misfortune? So, in this respect, like a beast so a man could be of one condition? [Wiśniewski 1760:82-83 (trans. AK)]

\footnotetext{
${ }^{19}$ Polish historian, Władysław Konopczyński, lists in this respect the political writings of Stefan Garczyński (1751), Antoni Wiśniewski (1760-62), Wincenty Skrzetuski (1773), Antoni Popławski (1774), Michał Karpowicz (1776-77), Józef Wybicki (1775), Andrzej Zamoyski (1778), and writers gathered around the Monitor-the magazine, published in 1765-1784. We should also add Stanisław Staszic (1790).

${ }^{20}$ Konopczyński paraphrases the original text of Garczyński (1751:128-129) written in old Polish.
}

Another shocking image of the peasantry of the times of serfdom was given by Stanisław Staszic (1970) in his Warnings for Poland. Based on an autopsy image, the overwhelming majority of Polish society is characterized by him as follows:

Five parts of the Polish nation stand before my eyes. I see millions of creatures, some of which are half-naked, others are covered with leather or a sharp coat. They are all dry, weary, stubborn, blackened, eyes sunken deep in their head, with breathless breasts constantly going. Gloomy, infatuated, and stupid, they feel little and think little-this is their greatest happiness. You can hardly discern a rational soul in them. At the first sight, their superficial figures show more resemblance to animals than to humans. The peasant-the peasant has the name of the last disdain...This is the delight of that part of the people on whom the fate of your Republic is drawn! Here is the man who feeds you! This is the condition of a farmer in Poland! [Staszic 1790:454 (trans. AK)]

However, after so many regrets and testimonies about "the hopeless situation of the regular people, Garczyński recommends only one modest breach in the prevailing system: let the peasants have at least one day off from enlistment a week, so they can go to markets and stock up on the most essential things and spend Sundays in God's way" (Konopczyński 1966:150 [trans. AK]). All of the above-mentioned political writers who pointed to the plight of the peasant, the injustice of the serf system, emphasized the need for deep reforms, but their voice was either poorly heard or quickly suppressed by the nobility and clergy, who saw a threat to their rights and freedoms in improving the lives of peasants.

The Constitution of the Duchy of Warsaw, given on July 22, 1807 by Napoleon Bonaparte, overthrew 
the former inequality of status. By proclaiming the principle of equality before the law (Article 4), it abolished the submission of the peasants, granting them personal freedom. However, no decision was made on granting them any property rights, nor was serfdom abolished. It caused a more complicated situation for the peasantry, especially since the later decree of December 21, 1807 granted the lords of the manors full ownership of peasant farms and allowed them to remove peasants from the land.

Since 1795, Poland lost its independence and till 1918, the Polish territory was split between Germany, Austria, and Russia. Different laws regarding peasants prevailed in different zones of partition, thus the abolition of serfdom occurred gradually on the Polish territory and differed in those zones. Finally, serfdom was abolished in Prussia in 1807, in Austria in 1848, in Russia in 1861, and in the Congress Kingdom of Poland in 1864 (Bardach et al. 1987:389-394). But, the abolition of serfdom did not fundamentally change the plight of the peasants and did little to improve their situation. Many peasants could not meet the new demands. They became free day-laborers, fell into debts, and lived in ever greater poverty than before, being still dependent on their employers.

The peasants' lives were encapsulated in the cycle of birth and death, cultivation of the soil, working, eating, and falling asleep. They hardly left any records or permanent traces, especially the written ones, because the vast majority of the peasants were illiterate. They did not participate in any discourse of society. They remained silent, sharing their fate with the factory workers (Madejska 2018; Urbaniak-Kopeć 2018) and servants (Kuciel-Frydryszak 2018). The working class lived from hand to mouth, laboriously upholding their existence and focusing all their efforts on it. In this way, a huge part of society was practically voiceless in literary discourses.

There were very perceptive and sensitive poets and writers who were carefully watching the lower class life and describing their situation. ${ }^{21}$ For instance, Władysław Reymont (1867-1925), a Polish novelist, the laureate of the Nobel Prize in Literature in 1924, wrote his best-known work titled Chłopi (The Peasants [1925]) on the base of his observations held in the village Lipce in Poland. In this award-winning four-volume novel, he illustrated the life of the peasant community, its customs, conflicts, normative rules, values, and conditions of life with ethnographic proficiency. Reymont provided a full, vivid picture of the Polish countryside gained from the position of intimate familiarity, but still, offering a picture of peasants observed and described by an intellectual, not by themselves.

Marceli Handelsman (1907a:47) points to a distorted view of the peasants in literary and historical works, which refer to a one-sided image of the peasantry created by the nobility on the base of the reports and accounts favorable to the lords. He gives an example of the Biography of the Peasant

\footnotetext{
${ }^{21}$ Polish writers who wrote about the fate of peasants were: Bolesław Prus in the novella Antek (1880), or his novels Anielka (1885) and Placówka [The Outpost, 1885-86]; Henryk Sienkiewicz (1893) in short stories Yanko the Musician or Za chlebem [For Bread]; Eliza Orzeszkowa in the novel Nad Niemnem [Over the Niemen, 1888]. In the poem Wolny najmita [The Free Day-Laborer], Maria Konopnicka talks about the problem of mass poverty among peasants. She ironically refers to the enfranchisement decree issued by Russia in 1864, which released the peasant from serfdom and offered them freedom and even small pieces of land. But, at the same time, it threw them into deep poverty. Having no help from the state, a free leaseholder was unable to cope with taxes and debts. Their freedom was illusory. In her novella Our Rip, Konopnicka gave the voice of a narrator to a young boy from the lower class (Four Novels 1888).
} 
written by Ignacy Lachnicki (1815), ${ }^{22}$ a Polish nobleman, who, being kind to his peasant, sees him only "as a child, a newborn" who comes to the privileged old noble family, and who entrusts himself to its care. This family, in turn, sees its own interest in choosing the appropriate means of disciplining and upbringing him, to prepare him to accept such an outstanding gift of being a serf to his masters (Handelsman 1907a:47). Thus, peasants are presented as people without any own history, with no origin, without tradition, modeled by their masters like clay figurines.

Describing the life of peasants, Lachnicki (1815:21 [trans. AK]) pictures the utopian scenes of their effective work, which means that they do not need to be whipped anymore, "the reasons have ceased, the need for reprimanding and pressure has disappeared before the intention, the power of lashing and urging has fallen." Although he, himself, emphasizes that the presented idyllic scenes are exceptional, they still contribute to discursive practices of idealizing the situation of the peasantry. Even defending the interests of peasants, even declaring explicit support for their rights to liberation, the nobility continued to use a very superficial and stereotypical image of the peasant. In his book O kmiotku polskim [About the Polish Yokel], Andrzej E. Koźmian (1843:5 [trans. AK]) wrote:

the time has come to work on liberating the Polish peasants; I believe everyone has to make this belief

${ }^{22}$ After the partitions of Poland, Lachnicki settled in Vilnius, where he voluntarily worked for the local community and implemented the ideas of the Enlightenment towards his peasants. He belonged to the Rascal Society (Towarzystwo Szubrawców), a moral association organized to resemble freemasonry, operating in Vilnius in the $19^{\text {th }}$ century with the goal of equalizing the rights of all citizens, improving the situation of peasants, and combating superstition, obscurantism, and ignorance (Hordyński 1883:18; Winnicka 1972:96). spread more and more and take root. Thus, the purpose of this little writing which...could be called the physiology of the Polish peasant, is a reminder of what he was, what our peasant always is; a hint of what his hopes are in him, what his future is, and finally, to feel pity for his misery and his violated rights.

But, by doing so, he also expressed an honest will "to mention all those who once and now became the protectors, guardians, benefactors of the rural people" (Koźmian 1843:6 [trans. AK]). In his work, he reflects on the etymology of the word "kmieć" (yokel), considers the origins of the peasants by referring to their second names, claiming that the rural people are the oldest inhabitants and workers on Polish soil, so they constitute the true national element.

He is always associated with [Polish soil], never looked for a foreign sun, never accepted anything from strangers to his soul. [Koźmian 1843:12 (trans. AK)]

Our rural people are the most important national element: an undeveloped element, underdeveloped, stagnant in its progress, but not spoiled, self-born, full of life and firmness. [Koźmian 1843:13 (trans. AK)]

Koźmian searches for the true Polish origin in the peasants, but, at the same time, he diminishes them as an "underdeveloped" part of the society that is inhibited in development. Reading this, we are dealing with a paradoxical stylistic measure of idealizing the peasants, and, at the same time, with their infantilization by the author. He also attributes to peasants other qualities, such as high religiousness and an aesthetic sense, presenting them as beautiful, handsome, and righteous people. "Simplicity, openness, and cheerfulness char- 
acterize the inhabitants of our land," he claims (Koźmian 1843:16). It seems that this is how the gentry would like to see their peasants. One may wonder, however, what is the relationship between this view and the real image of the peasants' lives? And, was an authentic peasants' voice able to break through this idyllic picture-at least as the softest whisper?

Publications about peasants were written for various purposes, among others, to prove the misconceptions about the torment of the peasantry or, as in the case of the publication O chtopach (Of Peasants) from 1847, to stimulate reformist tendencies among the nobility, to avoid retaliation by the peasants or impending socialism.

This book was written in large part before sad Galician events ${ }^{23}$ : what was once thought to be useful has now become indispensable. The holiest duty of decent citizens is to make every effort to order peasant relations: the imminent danger of socialism and communism cannot be reversed otherwise, the heavy debt of the past cannot be repaid in any other way. To grant righteous freedom so that they will not be tempted by lawlessness. This is to be a byword of these actions. [Of Peasants 1847:v-vi (trans. AK)]

Handelsman sees such a type of literature as a form of struggle for the self-interest of the nobility. "Always the interest of one's class, consciously

\footnotetext{
${ }^{23}$ The "sad Galician events" is a euphemistic expression that allows us to bypass and obscure the "Galician Slaughter," the real name of the events in Galicia in 1846, which consist of a peasant uprising against serfdom and manorial oppression. Galician peasants led by Jakub Szela attacked the Polish gentry in dozens of manors and brutally murdered their inhabitants. About 1000 noblemen were killed, and half a thousand manors were destroyed. Certainly, the uprising of the Galician peasants can be perceived as a dramatic event, a cry of despair, and, at the same time, as their retaliation for the centuries-old oppression.
}

or unconsciously, becomes the starting point for understanding the present and drawing plans for the future" (Handelsman 1907a:48 [trans. AK]).

To sum up, there existed writings about peasants, but not in their voices-those were messages and contents standing for the interests, views, and voices of other social classes and states. The peasantry could not bear witness to their humiliation or dramatic life situation, and, as the lowest illiterate part of society, they remained muted. None of their voices from the $18^{\text {th }}$ century prevailed, but that was about to change in the $19^{\text {th }}$ century.

\section{Gaining Literacy, Gaining the Voice}

The first peasant memoir, known more widely in the Polish culture, was written by Kazimierz Deczyński at the end of 1837, long before Thomas and Znaniecki started working on The Polish Peasant. The voice of Deczyński was preserved and passed on to the descendants by Marceli Handelsman (Deczyński 1907), who edited a handwritten 30page memoir deposited in the Polish Library in Paris, and enriched it with a historical overview (Handelsman 1907b), placing this autobiography in the context of particular events experienced by the memoirist (Handelsman 1907a). The whole thing was published in Polish under the title $\dot{Z} y$ wot chłopa polskiego na poczatku XIX wieku [The Life of a Polish Peasant at the Beginning of the $19^{\text {th }}$ Century]. Handelsman saw this memoir as a valuable source of knowledge on peasantry and peasants' relations with the nobility.

It would seem that here we deal with the instance of a meaningful breakthrough since a serf was able to enact his subjectivity by loudly expressing his complaint about peasants' fate. But, when we closely 
look at this story, it turns out that both Deczyński's course of life and the matter of writing his memoir or prospective publication illustrate rather explicit attempts to suppress his desire to write and to take his voice away-which, in fact, happened. During his lifetime, Deczyński did not publish his memoir, ${ }^{24}$ and its translation into French was intercepted by representatives of the nobility on charges of libeling Polish countrymen.

And, again, when we take a closer look at the biography of the author, it turns out that, at the moment of creating it, he was not a serf peasant, but a descendant of such a peasant, who, from childhood, watched the scenes of the humiliation of his parents by the local nobility and officials.

In fulfilling my duties [as the parish school teacher], I always watched as the Lord, the lessee, oppressed and raped the peasants of this village, among whom were also my parents and their numerous families. This indecent treatment of peasants made my heart even more envenomed and infused with hatred towards the tenants. I have never forgotten how, when I was still a little boy with my father, I often saw him hiding in a barn among sheaves of grain or somewhere under a thatched roof in a stable, cowshed, and often escaping into the forest when granger, steward, treasury, shooter, and court servants came to my father's house to take him to the court of the great Lord; and not being able to find my father when he hid well or ran away into the forest, they poke, push, beat, even with a whip or a stick on the back, reproach my crying moth-

\footnotetext{
${ }^{24}$ After divesting him of the French translation of the manuscript and a ban on publishing it in France, Deczyński returned to editing its original Polish version, but he lacked strength and resources and failed at publishing it (Handelsman 1907a:44). He died in France on December 28, 1838, at the age of 38 .
}

er with the most hideous words to make her tell where her husband was.

I could never forget it; how, often returning from the court from the Lord, I saw my father having his long hair torn out from his head, black eyes, not counting kulaks in the sides, with a fist or a leg, taken. [Deczyński 1907:54-55 (trans. AK)]

How did it happen that he was able to describe such scenes? First, of course, because he could write. His parents sent him to an elementary school in the local parish as a six-year-old boy, and when the school fell into decline, they sent him to another school. And when the father no longer had money to pay for the school, he continued looking for ways to provide him with an opportunity to become educated. He arranged a practice for his son with a friendly pastor so that he would not forget what he had learned thus far. Kazimierz was hired to write church records and register files. Finally, due to his father's efforts, Kazimierz gained the position of a teacher at the local school in Brodnia.

The second thing was the role of the father who appreciated the value of being literate and stimulated his son's development as much as he could. The third was the father's resistance observed by his son-the resistance that drowned in the stream of "unbearable sorrows and rapes." The father, himself, was a peasant aware of his rights and the fact of their breaking by the lords. He lamented the fate of his son, expressing regret that he could not provide him with a better future. "You see, my son, how hard we work, but this work is not hard for me. Above all my hardships, the most unbearable for me are the oppressions and rapes caused by our masters" (Deczyński 1907:52-53 [trans. $\mathrm{AK}])$. Therefore, here we have the father who talks 
to his son, who names the state of his oppression and indicates the guilty ones. For Kazimierz, his father is not only a role model, a great significant figure, but also someone who sets a clear direction of development and pushes Kazimierz to the educational path, guessing that this is the only way for his son to be promoted: "So that you do not become a victim of such unbearable unpleasantness and rapes, and handicaps, like me, I wish you, my son, a different state of life" (Deczyński 1907:52 [trans. AK]).

Shocking observations of the everyday life of peasants left a permanent mark on Kazimierz. His later attempts to assert the rights of peasants resulted in divesting him of a teaching position and sending him "as a punishment" to the front. This circumstance made him a soldier and later an immigrant in France, bringing the experience of detachment from his milieu. From this distant position, he could begin to write down his reflections on the life of Polish peasants. But, here begins another scene of the theater of silencing voices about the living conditions of Polish peasants. Already while writing his memoir, Deczyński encountered ostracism, accusations, and threats. The local committee forbade him from publishing the manuscript. For the nobility, the description of the actual behavior of the lords towards the peasants was treated as an insult, they did not see reasons for any accusations. The cause was

[t]he views of the then emigration on the inviolability of the past, the view that forbade any criticism, especially touching the peasants' issue. It was enough for Deczyński to describe the real life of Polish peasants to be ostracized, and his work to be regarded as a work in which the author-scolder "slanders" even on his homeland. This was the fundamental tone in emigration. Under these conditions, Deczyński could not expect a fair, impartial judgment over himself, he could not receive a judgment consistent with the principles of elementary justice. And because of that judgment, Deczyński's memoir was not published. [Handelsman 1907a:46-47 (trans. AK)]

Perhaps precisely because Deczyński was not a typical serf, since he went beyond the framework of his state and social position-as a teacher, as a soldier, as an emigrant-he could speak and his voice could ultimately be heard.

A few years before the publication of Deczyński's memoir, another work, Dwie dusze [Two Souls] by Jakub Bojko (1904), was issued in print. A folk writer, Jakub Bojko, became a teacher due to self-education. He taught children while working on his farm. He wrote poems and short stories successfully published in magazines. In his book, Bojko attempts to deal with serfdom as a state of mind that still inhabits the souls of peasants after liberation in 1848.

I can swear to it that in us, peasants, there atones, apart from our little soul, another one. And although it is the Jewish Talmud that writes that only a Jew, and only for the Sabbath, gets a second soul, I cry out boldly, let them do whatever they want to me, that the peasants, apart from their own, have a second soul!...The soul of a very old, ugly lady, who died in 1848 and was called serfdom, resides in us. This lady held our whole boorish tribe in captivity for over 400 years and killed a human in a peasant, and she simply made [him] trash, a machine with which it was possible to do whatever this lady wanted. And if, God forbid, this peasant would slightly oppose something, this lady had a way of knocking it out of his head, his children, 
and grandchildren for a hundred years. [Bojko 1904:2 (trans. AK)]

This horror of serfdom got into the blood of the people so much that to this day it is reflected in a glaring way, not only on the regular people, but even on those of his sons who even, due to schools, took high positions. The spirit of serfdom, the spirit of a slave, is in all of us, and whoever does not believe should read on. [Bojko 1904:4 (trans. AK)]

Based on his careful observations and reflections, he shares personal stories that describe the clash of sequacious and civic attitudes among the liberated peasants (Bojko 1904:9-10; see also: Jakubczak 1968:108). In this way, Bojko touches on the problem of collective trauma of slavery caused by serfdom.

And what when you join, for example, a higher official, secular or clergyman. Your soul escapes down to your heels, and the other one, serfdom, makes you a calf, a snowman, who then bends at the waist like a slave, and not only that he will not do anything good for himself, but sometimes the matter of his own brothers-he will sell it for free... [Bojko 1904:7 (trans. AK)]

It turns out that serfdom has left permanent scars, remaining a collective trauma that affects not only the consecutive generations of those who lived in the humiliation of slavery, but also those several generations after them. That is trauma recorded in the body, in thoughts, in attitudes, in the limitation of horizons. Interestingly, Bojko directs his voice to his peasant brothers-they are the addressees of his message.

You, peasant, you became a teacher! For the whole cottage with the chimney, you have risen above your peers who envy you this knowledge and think that you are wiser, it is not only for yourself that the peasant issue will have one more defender, and you, together with other peasant sons, you will not forget about the fate of those from whom you have strayed.

[Bojko 1904:8-9 (trans. AK)]

He appeals to the collective solidarity of peasants, especially those who have achieved social advancement. Pointing to the goal of social transformation of own social class, he employs the term "citizenship" with the idea of making peasants "citizens worthy of the name," "to get rid of the slave spirit as soon as possible" (Bojko 1904:10 [trans. AK]). At the same time, he shows the way of escaping from low self-esteem and the serfdom trauma-it is self-education, reading books and magazines, ${ }^{25}$ developing civic attitudes, raising interest in what is happening in the country.

This was the first such incisive and brilliantly written self-analysis that involved reflections on the entire state of the peasants based on their own observations and self-observations. It represented something more than just a complaint or wail. Autobiographies and memoirs were certainly a form of complaint, but, at the same time, the way of enacting their voice. As Katherine Lebow (2014:13) points out:

[the] social memoir has much in common with what, in other contexts, we would call witnessing or testimony, and was embedded in cultural assumptions about truth-telling and the rights and obligations of citizenship. While critics of the social memoir genre complained that it was too full of complaints, mem-

25 "[B]y the way-he writes-I will say that this slave-serf soul is not afraid of either holy water or the cross, but the most it is afraid of books and newspapers" (Bojko 1904:12 [trans. AK]). 
oirists presented their ability to complain as evidence of their subjecthood: I complain, therefore, I am.

Certainly, there were many status differences among the peasants themselves (Grabski 1938:51). A careful listener to their stories and voices would probably hear many miscellaneous ones. However, to represent all those diverse social groups, various stories, and voices should be heard. But, in the world where peasants' accounts are silenced or distorted, where their voices are muted in the discourse, this general silence equalizes them, and we tend to see them as uniformly suffering under the pillory of serfdom. The problem with generating knowledge about Polish peasants was to let them speak and express themselves. This could have been done if they would only achieve enough literacy to create such accounts, and someone will be ready to hear their voices $^{26}$ in all their diversity. That is what the subsequent memoir contests made possible.

\section{Polish Memoirism and Its Institutionalization}

The history of memoirs competitions in Poland did not finish with the first success and the instances of autobiographies of Jakub Wojciechowski (1930) and Władysław Berkan (1923). Their life stories gave way to forthcoming studies and the gathering of more and more autobiographical data by sociol-

\footnotetext{
${ }^{26}$ Stanisław Pigon (1885-1968) was such an explorer of the work of self-born peasant writers and an expert on the culture of the Polish countryside. He, himself, came from a rural family and with great effort, against all odds, obtained his higher education. To listen to the voice of the handicapped, together with the ethical and educational club "Eleusis," he collected before the First World War several dozen biographies of emigrant workers-with the help of a special questionnaire. He was also the editor of a thematic volume of the magazine Eleusis, filled with workers' autobiographies. The materials were rashly burnt after the outbreak of World War II (Jakubczak 1966:6).
}

ogists. Since then, a systematic collection of largescale autobiographical materials began.

In 1929, on the occasion of the Universal National Exhibition summarizing ten years of Polish State independence after World War I, Znaniecki announced another contest to gather autobiographies of the inhabitants of Poznan, which became the basis for his excellent book The City in Views of Its Inhabitants (1931). With this work, Znaniecki put a cornerstone for the development of urban studies in Poland (Dulczewski 1992:160). Following the view adopted by the Chicago Ecological School, he treated the city not as a spatial entity, but, according to the principle of the humanistic coefficient, as a "non-spatial humanistic whole that is realized in experiences and activities of people" (Sitek 2002:370 [trans. AK]). The method introduced by Znaniecki to investigate city issues by studying how these problems are reflected in the consciousness of its inhabitants was an innovative research approach. Using public competitions "became a habit for the new generation of Polish sociologists who utilized this method in many cities in Poland after World War II" (Dulczewski 1992:160).

Znaniecki raised students who took over his ways of asking research questions and collecting data. ${ }^{27}$ Each of them had the ambition to gather and use autobiographical materials in their studies and participated in the development of the biographical method. In the interwar period, a total of 18 public memoir competitions were organized, almost all by scientific institutions (see: Tab. 1).

\footnotetext{
${ }^{27}$ The disciples of Znaniecki were: Józef Chałasiński, Tadeusz Szczurkiewicz, Jan Szczepański, Stanisław Kowalski, Władysław Okiński, Jerzy Piotrowski, Wanda Stróżykówna-Mrozek, Zygmunt Dulczewski, Franciszek Mirek, and Walerian Adamski. Also Theodore Abel and Stanisław Andreski were under the influence of Znaniecki.
} 
Table 1. The list of Polish memoir competitions in the interwar period.

\begin{tabular}{|c|c|c|c|c|}
\hline No. & Year & Title & Organizer & $\begin{array}{l}\text { No. of } \\
\text { gathered } \\
\text { records }\end{array}$ \\
\hline 1 & 1921 & $\begin{array}{l}\text { Konkurs na życiorys własny robotnika } \\
\text { [Competition for an Autobiography of a Physical } \\
\text { Worker] }\end{array}$ & $\begin{array}{c}\text { Instytut Socjologiczny w Poznaniu [Institute of } \\
\text { Sociology in Poznan] } \\
\text { (Florian Znaniecki) }\end{array}$ & 149 \\
\hline 2 & 1921 & $\begin{array}{l}\text { Konkurs na pamiętnik pracy wyborczej } \\
\text { [Competition for a Diary Concerning Election } \\
\text { Work] }\end{array}$ & $\begin{array}{c}\text { Instytut Socjologiczny w Poznaniu [Institute of } \\
\text { Sociology in Poznan] } \\
\text { (Ludwika Dobrzyńska-Rybicka) }\end{array}$ & $?$ \\
\hline 3 & 1930 & $\begin{array}{l}\text { Konkurs “Czym było i jest dla Ciebie Miasto } \\
\text { Poznań?" } \\
\text { [Competition “What Poznan was and is for you?"] }\end{array}$ & $\begin{array}{c}\text { Instytut Socjologiczny w Poznaniu [Institute of } \\
\text { Sociology in Poznan] } \\
\text { (Ludwik M. Landau, Florian Znaniecki) }\end{array}$ & 27 \\
\hline 4 & 1931 & $\begin{array}{l}\text { Konkurs na pamiętniki bezrobotnych } \\
\text { [Competition for Memoirs of the Unemployed] }\end{array}$ & $\begin{array}{l}\text { Instytut Gospodarstwa Społecznego } \\
\text { [Institute of Social Economy] } \\
\text { (Ludwik Krzywicki) }\end{array}$ & 774 \\
\hline 5 & 1933 & $\begin{array}{l}\text { Konkurs na pamiętniki chłopów } \\
\text { [Competition for Memoirs of Peasants] }\end{array}$ & $\begin{array}{l}\text { Instytut Gospodarstwa Społecznego } \\
\text { [Institute of Social Economy] } \\
\text { (Irena Kosmowska) }\end{array}$ & 498 \\
\hline 6 & 1934 & $\begin{array}{l}\text { Konkurs na opis gospodarowania w gospodar- } \\
\text { stwach karłowatych } \\
\text { [Competition for the Description of Farming on } \\
\text { Small Farms] }\end{array}$ & $\begin{array}{l}\text { Państwowy Instytut Naukowy Gospodarstwa } \\
\text { Wiejskiego w Puławach } \\
\text { [The National Research Institute of Rural Farm- } \\
\text { ing in Pulawy] }\end{array}$ & $?$ \\
\hline 7 & 1935 & $\begin{array}{l}\text { Konkurs na życiorysy wiejskich działaczy spo- } \\
\text { łecznych } \\
\text { [Competition for Biographies of Rural Communi- } \\
\text { ty Activists] }\end{array}$ & $\begin{array}{l}\text { Instytut Socjologii Wsi SGGW } \\
\text { [Institute of Rural Sociology, Warsaw University } \\
\text { of Life Sciences] } \\
\text { (Władysław Grabski) }\end{array}$ & 404 \\
\hline 8 & 1935 & $\begin{array}{l}\text { Ankieta o kulturze proletariatu i samokształceniu } \\
\text { [Questionnaire on Proletarian Culture and } \\
\text { Self-Education] }\end{array}$ & $\begin{array}{l}\text { Szkoła Nauk Społecznych TUR w Krakowie } \\
\text { [TUR School of Social Sciences in Cracow] }\end{array}$ & 104 \\
\hline 9 & 1936 & $\begin{array}{l}\text { Konkurs na opis życia, prac, przemyśleń i dążeń } \\
\text { młodzieży wiejskiej } \\
\text { [Competition for Description of Life, Work, Re- } \\
\text { flections, and Aspirations of the Rural Youth] }\end{array}$ & $\begin{array}{c}\text { Państwowy Instytut Kultury Wsi } \\
\text { [State Institute of Rural Culture] and } \\
\text { Journal Przysposobienie Rolnicze [Farmer Education] } \\
\text { (Józef Chałasiński) }\end{array}$ & 1544 \\
\hline 10 & 1936 & $\begin{array}{l}\text { Konkurs na pamiętniki emigrantów } \\
\text { [Competition for Memoirs of Polish Emigrants } \\
\text { (in France, US, Canada, Uruguay, Brazil, Argenti- } \\
\text { na, Paraguay)] }\end{array}$ & $\begin{array}{l}\text { Instytut Gospodarstwa Społecznego } \\
\text { [Institute of Social Economy] } \\
\text { (Ludwik Krzywicki) }\end{array}$ & 212 \\
\hline 11 & 1937 & $\begin{array}{l}\text { Konkurs na pamiętniki lekarzy } \\
\text { [Competition for Memoirs of Physicians] }\end{array}$ & $\begin{array}{l}\text { Zakład Ubezpieczeń Społecznych w Warszawie } \\
\text { [Social Insurance Company in Warsaw] }\end{array}$ & 51 \\
\hline 12 & 1937 & $\begin{array}{l}\text { Konkurs na pamiętniki rolnika działacza samo- } \\
\text { rządowego } \\
\text { [Competition for Memoirs of Local Government } \\
\text { Activist Farmers] }\end{array}$ & $\begin{array}{l}\text { Instytut Pracy Samorządu Terytorialnego [Local } \\
\text { Government's Institute of Labor] }\end{array}$ & ? \\
\hline
\end{tabular}




\begin{tabular}{|c|c|c|c|c|}
\hline 13 & 1937 & $\begin{array}{l}\text { Konkurs na życiorysy bezrobotnych } \\
\text { [Competition for Autobiographies of the Unem- } \\
\text { ployed] }\end{array}$ & $\begin{array}{c}\text { Polski Instytut Socjologiczny } \\
\text { w Poznaniu [Polish Sociological Institute in } \\
\text { Poznan] }\end{array}$ & 605 \\
\hline 14 & 1937 & $\begin{array}{l}\text { Wychowankowie szkół rolniczych o swej pracy, } \\
\text { życiu i dążeniach } \\
\text { [Agricultural School Students about Their Work, } \\
\text { Life, and Aspirations] }\end{array}$ & (Stanisław Łukaszewicz) & $?$ \\
\hline 15 & 1937 & $\begin{array}{l}\text { Życiorysy Ślązaków } \\
\text { [Autobiographies of Silesians] }\end{array}$ & $\begin{array}{c}\text { Polski Instytut Socjologiczny } \\
\text { w Poznaniu [Polish Sociological Institute in } \\
\text { Poznan] } \\
\text { (Jan Szczepański) }\end{array}$ & 206 \\
\hline 16 & 1937 & $\begin{array}{l}\text { Konkurs na życiorysy wychowanków Uniwersy- } \\
\text { tetów Ludowych } \\
\text { [Competition for Autobiographies of the Alumni } \\
\text { of Folk Universities] }\end{array}$ & $\begin{array}{l}\text { Państwowy Instytut Kultury Wsi } \\
\text { [State Institute of Rural Culture] }\end{array}$ & $?$ \\
\hline 17 & 1937 & $\begin{array}{l}\text { Konkurs na najlepszą autobiografię młodzieńca } \\
\text { żydowskiego } \\
\text { [Competition for the Best Autobiography of } \\
\text { a Young Jewish Man] }\end{array}$ & $\begin{array}{l}\text { Żydowski Instytut Naukowy } \\
\text { [Jewish Scientific Institute] }\end{array}$ & $303^{*}$ \\
\hline 18 & 1938 & $\begin{array}{l}\text { Konkurs na życiorysy nauczycieli } \\
\text { [Competition for the Autobiographies of Teach- } \\
\text { ers] }\end{array}$ & $\begin{array}{c}\text { Instytut Pedagogiczny ZNP w Warszawie } \\
\text { [Pedagogical Institute of the Polish Teachers } \\
\text { Union in Warsaw] }\end{array}$ & ? \\
\hline
\end{tabular}

* In this competition, a total of 17,000 pages was obtained. Besides memoirs, it included over 20 diaries, letters, literary works, photographs, and drawings. Participants sent it from nine countries and over 150 cities (Jakubczak 1966:12).

Source: Own compilation based on Jakubczak 1966.

From 1931, the Institute of Social Economy [Instytut Gospodarstwa Społecznego] systematically organized competitions for memoirs of workers and peasants. The biggest success was the competition organized by Józef Chałasiński with the journal Przysposobienie Rolnicze [Farmer Education] in 1936. The topic of this competition was: "Description of my life, works, reflections, and aspirations." The organizers received 1544 autobiographical descriptions from young rural activists. Based on these data, Józef Chałasiński wrote his fundamental four-volume work: The Young Generation of Peasants ([1938] 1984). This made Polish interwar sociology an incredible "generator" of such kinds of data, and the unusual phenomenon in this respect on a global scale.
The largest post-war work continuing the endeavor of Thomas and Znaniecki, as well as The Young Generation of Peasants by Józef Chałasiński was The Young Generation of the Villages of People's Poland (1964-1980) - an eight-volume work containing rich autobiographical materials. The study includes methodological input by Józef Chałasiński and his collaborators: Eugenia Jagiełło-Łysiowa, Bronisław Gołębiowski, Franciszek Jakubczak, Zdzisław Grzelak, Wiesław Myśliwski, Piotr Banaczowski, and Dyzma Gałaj. These elaborations showed the third generation of peasants, the image of a Polish village, and its contribution to national culture. 
Table 2. The list of Polish memoir competitions in the post-war period (1946-1950).

\begin{tabular}{|c|c|c|c|c|}
\hline No. & Year & Title & Organizer & $\begin{array}{l}\text { No. of } \\
\text { gathered } \\
\text { records }\end{array}$ \\
\hline 1 & 1946 & $\begin{array}{l}\text { Konkurs na pamiętnik robotnika z czasów } \\
\text { okupacji } \\
\text { [Competition for a Worker's Memoir from the } \\
\text { Occupation Time] }\end{array}$ & $\begin{array}{l}\text { Centralna Komisja Związków Zawodowych } \\
\text { [The Central Commission of Trade Unions] } \\
\text { and newspaper Ekspres Ilustrowany [Express } \\
\text { Illustrated] }\end{array}$ & 116 \\
\hline 2 & 1946 & $\begin{array}{l}\text { Konkurs na opis przeżyć, przemyśleń } \\
\text { i spostrzeżeń młodzieży wiejskiej w czasie } \\
\text { pobytu poza Polską oraz po powrocie do kraju } \\
\text { [Competition for the Description of } \\
\text { Experiences, Thoughts, and Insights of the } \\
\text { Rural Youth During Their Stay Outside of } \\
\text { Poland and After Returning to the Country] }\end{array}$ & $\begin{array}{l}\text { Polski Instytut Służby Społecznej w Łodzi } \\
\text { [Polish Institute of Social Services in Lodz] } \\
\text { (an announcement in the form of a leaflet) }\end{array}$ & 14 \\
\hline 3 & 1946 & $\begin{array}{l}\text { Pamiętniki lub wypowiedzi dotyczące okupacji } \\
\text { niemieckiej } \\
\text { [Memoirs or Accounts about the German } \\
\text { Occupation] }\end{array}$ & $\begin{array}{c}\text { Instytut Zachodni w Poznaniu [West Institute } \\
\text { in Poznan] and Poznańskie Towarzystwo } \\
\text { Przyjaciół Nauk } \\
\text { [Poznan Society of Friends of Sciences] }\end{array}$ & $?$ \\
\hline 4 & 1946 & $\begin{array}{l}\text { Przeżycia dzieci żydowskich z okresu okupacji } \\
\text { niemieckiej } \\
\text { [Experiences of Jewish Children during the } \\
\text { German Occupation] }\end{array}$ & $\begin{array}{c}\text { Centralna Żydowska Komisja Historyczna } \\
\text { w Łodzi [Central Jewish Historical Commission } \\
\text { in Lodz] }\end{array}$ & $?$ \\
\hline 5 & 1946 & $\begin{array}{l}\text { Wspomnienia młodzieży wielkopolskiej z lat } \\
\text { okupacji } \\
\text { [Memoirs of the Greater Poland Youth from the } \\
\text { German Occupation of 1939-1945] }\end{array}$ & $\begin{array}{l}\text { Instytut Zachodni } \\
\text { [West Institute] } \\
\text { (K. Strzałkowski) }\end{array}$ & $?$ \\
\hline 6 & 1946 & $\begin{array}{l}\text { "Warszawa moich wspomnień" - konkurs } \\
\text { literacko-historyczny } \\
\text { [“Warsaw in My Memories"-Literary and } \\
\text { Historical Competition] }\end{array}$ & $\begin{array}{c}\text { Redakcja gazety Stolica } \\
\text { [Editorial office of the Capital City newspaper] }\end{array}$ & 102 \\
\hline 7 & 1947 & $\begin{array}{l}\text { Konkurs "Wspomnienia z Powstania } \\
\text { Warszawskiego" } \\
\text { [Competition "Memories of the Warsaw } \\
\text { Uprising" (children under the age of 16)] }\end{array}$ & $\begin{array}{c}\text { Czasopisma Przyjaciel dzieci, Robotnik } \\
\text { [Magazines Children's Friend and The Worker] }\end{array}$ & 126 \\
\hline 8 & 1947 & $\begin{array}{l}\text { "Moje najdawniejsze wspomnienia } \\
\text { o Warszawie" } \\
\text { [“My Oldest Memories of Warsaw”] }\end{array}$ & $\begin{array}{l}\text { Czasopismo Wieczór } \\
\text { [Magazine Evening] }\end{array}$ & $?$ \\
\hline 9 & 1947 & $\begin{array}{l}\text { Konkurs na opis udziału w walce } \mathrm{z} \text { Niemcami } \\
\mathrm{w} \text { latach 1939-1945 } \\
\text { [Competition for the Description of the } \\
\text { Participation in the Fight against Germany in } \\
\text { 1939-1945] }\end{array}$ & $\begin{array}{c}\text { Zakład Historii i Socjologii Wsi Uniwersytetu } \\
\text { Poznańskiego } \\
\text { [Department of Rural History and Sociology } \\
\text { of the University of Poznan]; appeal in Nowe } \\
\text { Wyzwolenie [New Liberation] }\end{array}$ & $?$ \\
\hline
\end{tabular}




\begin{tabular}{|c|c|c|c|c|}
\hline 10 & 1947 & $\begin{array}{l}\text { Ankieta "Niemiecki obóz koncentracyjny jako } \\
\text { szkoła słowiańskich charakterów" } \\
\text { [Survey on Source Materials for the Monograph } \\
\text { "German Concentration Camp as a School of } \\
\text { Slavic Characters"] }\end{array}$ & $\begin{array}{l}\text { Tygodnik Powszechny } \\
\text { [Weekly Common] }\end{array}$ & $?$ \\
\hline 11 & 1947 & $\begin{array}{l}\text { Konkurs “Do jakiego zawodu chciałbym się } \\
\text { przygotowywać i dlaczego?" } \\
\text { [Competition Addressed to Rural Youth: “What } \\
\text { Profession Would I Like to Prepare for and } \\
\text { Why?"] }\end{array}$ & $\begin{array}{c}\text { Editorial Board of magazine Wici; } \\
\text { Zakład Socjologii Szkoły Głównej } \\
\text { Gospodarstwa Wiejskiego } \\
\text { [Department of Sociology of the Warsaw } \\
\text { University of Life Sciences] } \\
\text { Instytut Kultury Wsi przy WSGW w Łodzi } \\
\text { [Institute of Rural Culture at the University of } \\
\text { Life Sciences in Lodz] }\end{array}$ & 252 \\
\hline 12 & 1947 & $\begin{array}{l}\text { Konkurs "Moja droga do szkoły rolniczej i ze } \\
\text { szkoły rolniczej do wsi" } \\
\text { [Competition "My Path to Agricultural School } \\
\text { and from Agricultural School to the Village"] }\end{array}$ & $\begin{array}{c}\text { Editorial Board of magazine } \\
\text { Wieś [Village] }\end{array}$ & $?$ \\
\hline 13 & 1947 & $\begin{array}{l}\text { Konkurs na życiorys górnika } \\
\text { [Competition for the Biography of a Miner] }\end{array}$ & $\begin{array}{l}\text { Centralny Ośrodek Kulturalno-Oświatowy } \\
\text { CRZZ w Sosnowcu } \\
\text { [Central Cultural and Educational Center at the } \\
\text { CRZZ in Sosnowiec] } \\
\text { and magazine Górnik [The Miner] }\end{array}$ & 115 \\
\hline 14 & 1947 & $\begin{array}{l}\text { Konkurs "Charakterystyka mojego środowiska } \\
\text { akademickiego" } \\
\text { [Competition "Characteristics of My Academic } \\
\text { Environment"] }\end{array}$ & $\begin{array}{c}\text { Editorial Board of Przeglad Akademicki [Academic } \\
\text { Review] (an announcement in the form of } \\
\text { a poster) }\end{array}$ & ? \\
\hline 15 & 1947 & $\begin{array}{l}\text { Wielki konkurs studencki "Moja droga do } \\
\text { wyższej uczelni" } \\
\text { [Great Student Competition “My Way to the } \\
\text { University"] }\end{array}$ & Tygodnik Po Prostu [Weekly Just Because] & ? \\
\hline 16 & 1947 & $\begin{array}{l}\text { Konkurs na pamiętniki o wyścigu pracy, } \\
\text { działalności na wsi oraz w szkole i na uczelni } \\
\text { [Competition for Memoirs about the Race for } \\
\text { Work, Activities in the Countryside and at the } \\
\text { University] }\end{array}$ & $\begin{array}{l}\text { Związek Młodzieży Wiejskiej } \\
\text { [Rural Youth Union] } \\
\text { and magazine Walka Młodych } \\
\text { [The Youth Fight] }\end{array}$ & ? \\
\hline 17 & 1947 & $\begin{array}{l}\text { Konkurs "Warszawa moich wspomnień" } \\
\text { [Competition "Warsaw in My Memories"] }\end{array}$ & Magazine Stolica [Capital City] & 102 \\
\hline 18 & 1947 & $\begin{array}{l}\text { Konkurs na pamiętniki Łodzianina } \\
\text { [Competition for Memoirs of the Inhabitants of } \\
\text { Lodz] }\end{array}$ & $\begin{array}{c}\text { Instytut Socjologii UŁ [Institute of Sociology, } \\
\text { University of Lodz] and Przeglad Socjologiczny } \\
\text { [Sociological Review] } \\
\text { (Józef Chałasiński, Natalia Gąsiorowska- } \\
\text { Grabowska, Helena Radlińska, Jan } \\
\text { Szczepański) }\end{array}$ & 18 \\
\hline
\end{tabular}




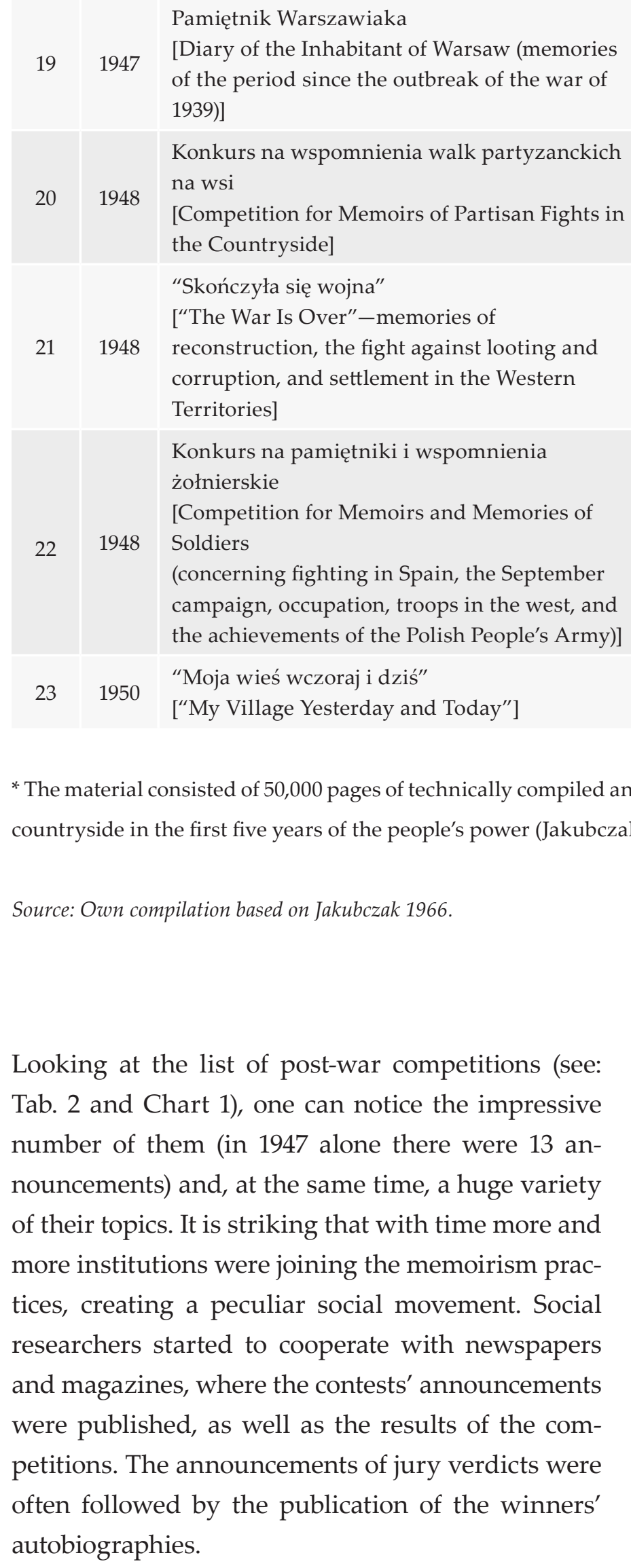

Source: Own compilation based on Jakubczak 1966.

Looking at the list of post-war competitions (see: Tab. 2 and Chart 1), one can notice the impressive number of them (in 1947 alone there were 13 announcements) and, at the same time, a huge variety of their topics. It is striking that with time more and more institutions were joining the memoirism practices, creating a peculiar social movement. Social researchers started to cooperate with newspapers and magazines, where the contests' announcements were published, as well as the results of the competitions. The announcements of jury verdicts were often followed by the publication of the winners' autobiographies.
Instytut Badań Warszawy Uniwersytetu Warszawskiego

[Institute of Warsaw Research at the University of Warsaw]

Dziennik Ludowy

[People's Journal]

Robotnik
[The Worker]

\begin{abstract}
* The material consisted of 50,000 pages of technically compiled and organized accounts relating to the transformations of the Polish countryside in the first five years of the people's power (Jakubczak 1966:17).
\end{abstract}

The announcements of memoir contests and sharing life records in publications have become extremely popular. ${ }^{28}$ The social memoirism movement was gathering more and more momentum. Thousands of people responded to the contests' calls and offered their life records. Franciszek Jakubczak counted that during the period 1921-

\footnotetext{
${ }^{28}$ The memoirs were systematically published by the Polish institutions: Institute of Social Economy [Instytut Gospodarstwa Społecznego], the Polish Sociological Institute [Polski Instytut Socjologiczny], the Institute of Rural Sociology of the Warsaw University of Life Sciences [Instytut Socjologii Wsi Szkoły Głównej Gospodarstwa Wiejskiego], and the National Institute of Rural Culture [Państwowy Instytut Kultury Wsi] (Kraśko 1996:67).
} 
Chart 1. Number of Polish memoir competitions in the post-war period (1946-1966).

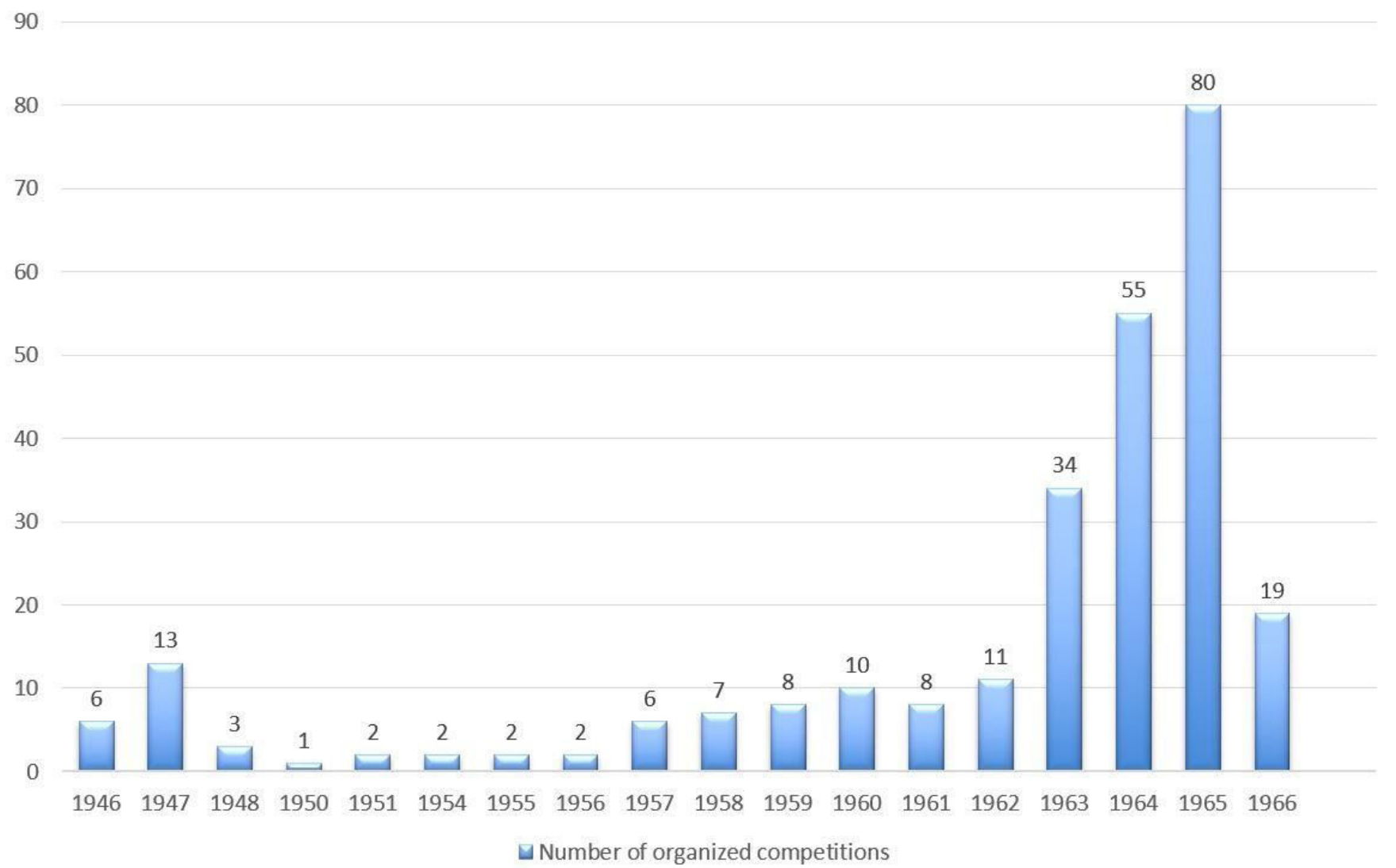

Source: Own study based on Jakubczak 1966.

1966 in Poland, 307 memoir competitions were organized, wherein 280 of them-in the Polish People's Republic. The estimated number of participants of these competitions reached 200,000 authors, and the summarized productivity of this autobiographical work was approximately 2 million pages of typescript.

Certainly, the application of the autobiographical method contributed to the development of Polish sociology and became its characteristic feature, adding to the knowledge about the condition of Polish society, especially about the life and situation of the underprivileged (Znaniecki [1923] 1976; Chałasiński 1971; 1972; 1974; 1982; Kwilecki 2011:327).

At the end of the 1960s, two outstanding scholars from the Polish Academy of Sciences, Jan Szczepański and Józef Chałasiński, came up with the idea of creating an institution intended to collect manifestations of human consciousness in the form of memoirs and other written records. Their idea was to continue the work initiated by Florian Znaniecki and William Thomas by gathering rich information on Polish society, based on life records and personal accounts. The Society of Friends 
of Memoirism [Towarzystwo Przyjaciół Pamiętnikarstwa], formally established in 1969, was the first institution in Poland to collect oral histories and traces of everyday life of ordinary people. From 1971, the society started to publish the quarterly Polish Memoirism, edited by Franciszek Jakubczak, with the mission:

To create a vital center of the scientific and cultural-civic movement, uniting scholars, authors, activists, and peasant workers, and diarists, and to provide it with lasting and effective fostering-this is the most general goal that the editorial office intends to implement with the best efforts and cooperation of all of the kind people. [Polish Memoirism 1971 1(1):2 (trans. AK)]

In 1976, Jan Szczepański (1976:38 [trans. AK]) concluded: "Never before, and in any country, has so much material been collected as in the Polish People's Republic. Tens of thousands of diaries, autobiographies, memories, et cetera were collected in hundreds of competitions. They gave huge resources of information about the changes in Polish society."

At the same time, one may observe the gradual separation of memoir competitions from the background of scientific institutes and the more vivid capturing of this idea by weekly magazines or newspapers. Over time, the editorial staff of magazines took over the organization of memoir competitions, making the gathered materials interesting content published on their pages, thus strengthening ties with their readers. However, scientific institutions were gradually losing interest in them.

It should be added that the memoirs easily fell prey to the propaganda machine of the commu- nist people's state. Especially in their mass, they could become both: a form of symbolic violence against memoirists-suggesting to the authors what to write about and how to present their lives to be accepted, and to the recipients of this literary form, for whom the narratives became a model of experiencing socialist life. Hanna Palska points out that in the 1940s and 1950s, Polish memoirs were strongly entangled in ideology since the biography was supposed to be a political instrument. The propaganda machine of the socialist people's state treated the autobiographies extremely instrumentally. Each autobiography-journalistic, literary, or obtained through competitions-was a tool to serve the system. "It was an era in which the process of the political unification of 'competition autobiographies' [and] of using autobiography for political purposes...reached its apogee" (Palska 1997:13 [trans. AK], see also: Czyżewski 1992).

Additionally, intense development of quantitative sociology, survey research, and the advancements in statistical analyses, which began to dominate Polish sociology from the 1960s, pushed memoirist practices to the margin of interest. Both the autobiographical approach, as well as a peculiar method of gathering personal documents through the public contests began to be marginalized under the pressure of new research methods. Qualitative sociology, understood as a general orientation in social investigations, "a qualitative way of thinking about the human experience," which allows reaching the subjective meanings of individuals (Konecki 2017:144), was reborn in Poland only in the 1990s. This does not mean that Polish sociologists have given up on biographical research ${ }^{29}$ or ceased us-

\footnotetext{
${ }^{29}$ On the contrary, the biographical method developed dynamically, although recently it primarily relates to data obtained in the presence of the researcher, like autobiographical
} 
ing such excellent materials as autobiographies. Contests for diaries have not been abandoned, ${ }^{30}$ although as a research practice, they have clearly lost momentum, and the scale of this phenomenon has significantly decreased. Polish researchers still use the archival materials, obtained as a result of competitions, to analyze and re-analyze the preserved narratives. $^{31}$

Many of the memoirs obtained in the competitions were lost or damaged during the war. Some of the archival materials went to the Society of Friends of Memoirism. However, in the 1990s, during the political transformation, many of them were destroyed or discarded. A small part of the saved materials went to the Archives of New Files [Archiwum Akt Nowych] (Posłuszny and Kubicki 2019:97). The rest were protected by the KARTA Center Archive, an independent non-governmental organization keeping the largest social archive of the $20^{\text {th }}$ century in Poland. ${ }^{32}$

narrative interviews or life stories evoked during biographical interviews. See: Rokuszewska-Pawełek (2002); Kaźmierska (2012).

${ }^{30}$ For example, at the turn of the century, the Institute of Social Economy announced another edition of the competition for the memoirs of the unemployed, for which 1,635 life records were submitted (Posłuszny and Kubicki 2019:99). It is also worth mentioning the research of Wojciech Dolinski (2012), who carried out a study on the identification of members of Polish society with the European Union using memoirs obtained through competition. Even now, during the epidemiological lock-down of 2020, the Institute of Philosophy and Sociology of the Polish Academy of Sciences, the Institute of Sociology of the University of Warsaw, and the Institute of Polish Culture of the University of Warsaw announced a competition for diaries from the time of the coronavirus pandemic (see: https://edupolis.pl/pamietniki-pandemii-konkurs/).

${ }^{31}$ See: Grabski 1936; Gołębiowski and Grzelak 1971; Gołębiowski 1977; Szarota 1978; Budzyński 1993; 1997; 2003; Palska 1997; 1998; Sułek 2007; Pawłowska 2015; Praczyk 2018; Rura 2019.

${ }^{32}$ KARTA outlined its mission: "We discover, protect, and popularize history from the perspective of the individual" (The KARTA Center Archive, see: https://karta.org.pl/22 [trans. AK]). See also: Gluza 2012; Łuba 2019.

\section{Discussion}

In this article, I put forward a thesis about the great role of Thomas and Znaniecki in triggering the phenomenon of regaining collective memory of the life experiences and thoughts of lower social classes. The influence of the ideas contained in The Polish Peasant on the development of Polish social memoirism seems to be obvious. ${ }^{33}$ The research practice of mass gathering of autobiographies and other life records started to develop rapidly after Znaniecki's return to Poland in 1920. The success of this enterprise was related not only to the impact of the monumental work of two scholars and the aura that surrounded its creators, but, above all, to the institutional activities taken by Znaniecki after his return to his homeland. Although, of course, his actions had to fit the fertile socio-cultural ground and people who were ready to follow him in a new approach in empirical research. But, a question may be raised as to whether this massive activity of giving the voice to the disadvantaged social groups was the intended goal or a side effect of the research procedures undertaken by Znaniecki and his disciples. Was he particularly interested in the lowest strata of society?

After his youthful fascination with the salons of Warsaw intelligentsia, where he wanted to shine, Znaniecki later criticized their intellectual apathy

\footnotetext{
${ }^{33}$ Analyzing the quarterly Pamiętnikarstwo Polskie [Polish Memoirism], Krzysztof Dunin-Wąsowicz (1974:206 [trans. AK]) accused the editors of excessive promotion of social memoirism, carried out in the spirit of Znaniecki's approach, at the expense of omitting previous periods of memoir creation. "Memoirism...is a very old phenomenon and is of interest to many sciences," meanwhile "for the authors and editors of the magazine, it is primarily Jakub Wojciechowski and The Polish Peasant." Apparently, for the Society of Friends of Memoirism, the history of memoirs, indeed, started with Znaniecki, and they were especially interested in contemporary, folk, emancipatory memoirism.
} 
and rejected class aspirations. "As "As a democrat[he wrote]-I concluded that the social role of the family aristocracy...is becoming more and more useless. However-[he did not fail to add]-I felt my reluctance towards any contacts with uneducated people" (Znaniecki [1920] 1978:36 [trans. AK]). In another part of his autobiography, Znaniecki ([1920] 1978:40 [trans. AK]) writes:

I freed myself...from the rest of my earlier aspirations for aristocratic social distinction, I gave up much of the European formalism and began to appreciate the simplicity of personal relationships in this country [America]. Democratism, previously accepted by me for intellectual reasons, but not to my liking emotionally, became more authentic in me, in the sense that I was not offended by the familiarity of uneducated people, although I would not say that they did not bore me...I am still sincerely convinced that democratism should only be reduced to equal opportunities, but it cannot be a mob government. The slogan of human equality is not only false, but socially harmful in the long run, regardless of its provisional usefulness in destroying old institutions which, by sanctioning a political and social hierarchy based on external criteria, hinder the development of a hierarchy based on the social value of human individuals.

\footnotetext{
${ }^{34}$ Describing himself as 18 or 19 years old, he wrote: "It was also a time when my temporarily revived aristocratic aspirations, as a consequence of my dealing with the living standards of the highest aristocracy, suffered a final defeat. It is surprising, however, that this double shock not only did not diminish the intensity of my ambitions and my self-confidence, but intensified them to the greatest extent. I gave up the idea of belonging to the aristocratic class. My ambition and the awareness that there was an unattainable limit here made me move towards other goals, reaching higher than I have ever dared to dream before. I was no longer satisfied with becoming someone great for my nation, I was striving for fame and importance throughout the world" (Znaniecki [1920] 1978:34 [trans. AK]).
}

The change in Znaniecki's attitude has been described as a move from the position of feeling "reluctance towards any contacts with uneducated people" into being "not offended by the familiarity of lower-class people" (albeit they bored him). Perhaps the matter was different in the case of his relations with the subjects of the study. It is difficult to ascertain nowadays. But, the question remainsDoes this emotional shift not seem to be too weak to support research interest in the peasants and working-class-viewed by Znaniecki as dull, uneducated people?

The very fact of writing such a monumental indepth monograph on Polish peasants may prove the authors' respect and attention towards the heroes of their work. Peasant families are given the floorthey speak through the correspondence exchanged between them. The source material is treated with care and accuracy, well-organized, and meticulously elaborated. The narration presented in The Polish Peasant is impressive, yet, at closer inspection, it is possible to find some unsettling fractures that prompt a different possible reading.

The first thing that strikes in this work is the parallelism of the narrative. As if the voice of Polish peasants and the voices of researchers ran parallel, occasionally touching each other. It is especially overwhelming when reading the third volume, Life Record of an Immigrant. Admittedly, the narrative of Władek Wiśniewski unfolds on his terms-he is given space for his speech, to tell a personal story with his words, but the whole of his account is framed by the narrative of the researchers. From the very beginning, they establish a way of reading it, anticipating in the introduction, how the story of Władek should be interpreted and prompting the proper reading in the consecutive footnotes through the 
text. The authors prepare the ground for Władek's narration as follows:

The material of our study is the autobiography of a Polish immigrant, written at our request three years ago. We hardly need to emphasize that the interest of this autobiography is exclusively scientific, not historical; the personality of the author is entirely insignificant from the point of view of the cultural development of Polish society, since he is a typical representative of the culturally passive mass which, under the present conditions and at the present stage of social evolution, constitutes in every civilized society the enormous majority of the population and whose only role seems to be to maintain, by innumerable and indefinitely repeated routine activities, a certain minimum of civilization in mankind at large, without being able to increase this minimum otherwise than by slowly assimilating and reproducing, very partially and inadequately, a few of the new cultural values produced by a small minority of creators and inventors. But, precisely for this reason, a record of this type can claim a great scientific and practical importance-greater perhaps than that of a creative man; for only the study of the commonplace man can make us understand why there are commonplace men. It makes us realize also that the greatest defect of our entire civilization has been precisely the existence of a culturally passive mass, that every noncreative personality is an educational failure. It will show the sources of such failures and thus open the way for a more successful social education in the future. [Thomas and Znaniecki 1919:81-82]

For the researchers, Władek was an educational failure, a "miscarriage case," ${ }^{35}$ a deviant, classified by

\footnotetext{
${ }^{35}$ In the Polish translation from 1976, this exact term "a miscarriage case" was used.
}

them as a representative of a particular section of Polish society, an example of a certain social class, "whose life is an alternation of periods during which he drifts into Bohemianism with periods of Philistinization, and shows a gradual increase of Philistine tendencies in the total curve of its evolution" (Thomas and Znaniecki 1919:82). In defense of such an external and distant approach to Władek, the authors present the argument that his biography sheds some light on the evolution taking place in the social layer to which he belongs (Thomas and Znaniecki 1919:83).

Interestingly, the authors did not provide the source of their belief that Władek was a typical instance since there were no other memoirs to compare with, and to state if he, indeed, was "typical" or "atypical." They started with the assumption that he represented the group they were interested in and, based on his story, they built an illustration of their theoretical model. Consequently, it is difficult to document the reasoning path from the autobiographical records to theoretical elaborations and conclusions reached by the authors. ${ }^{36}$

\footnotetext{
${ }^{36}$ In his appraisal of The Polish Peasant, Herbert Blumer ([1969] 1998:120-121) made a similar argument: "In the absence of comparable studies of other societies which can serve as a test of the authors' generalizations and theories, we are not in a position to decide categorically on their truth or falsity...The problem, then, which confronts us here is that of the relation between their materials and their theoretical analysis...It seems quite clear that Thomas and Znaniecki did not derive all of their theoretical conceptions from the materials which are contained in their volumes, or from similar materials which they did not put into their volumes. Perhaps not even the major theoretical conceptions were derived from them." The memoir competitions as a research strategy somehow responded to the Blumerian criticism of The Polish Peasant by giving access to the life records in a huge mass and making possible the comparisons and building typologies grounded in the data. However, Blumer's discussion on the value of personal documents, and his doubts about the method, announced in 1939, came many years after Znaniecki had launched a "huge machine" for producing personal documents in Poland, and without knowing about those actions taken by Polish scholars.
} 
The relationship between the author of the autobiographical record and the researchers is also interesting here. The subject of the research is only a provider of the initial material, and the researchers deal with it in a way they consider right. At the point when Władek is paid for the work (\$300 for the written memoir), Thomas and Znaniecki, as its holders, do not consult Władek anymore. They do not look for new layers of meanings, nor discuss with him their concepts, do not agree on them with the author of the life record. The scientific work is held over him. They classify him as a Bohemian or a Philistine, without sparing any evaluative descriptions. It is hard to resist the impression that they typologize the way of his life and "attach" him to this typology like an entomologist who pins an insect. He remains only a case in which the general tendencies studied by them could be expressed or illustrated. The participation of studied individuals in the interpretations and reinterpretations of the researcher does not exist in this case. The asymmetry of this relationship is revealed in the passage when the authors admit:

The sincerity of the autobiography is unmistakable. Its source is the self-complacency of the author, who naively accepted the suggestion of the editors, thought everything about him is interesting to others as it was to himself and did not distinguish at all between scientific and immediate interest...He did not know our standards, and any coloring or omissions can hardly hinder our understanding of his personality. [Thomas and Znaniecki 1919:86-87]

One may see this as the old-fashioned ethical standards of the research practice from the beginning of the $20^{\text {th }}$ century when the researchers did not reflect on the hierarchy and power relations they established in the field of their investigations. But, it is difficult to not recall here the considerations on the "great erasure" in terms of the institutional legacy of imperialism as "a pattern in colonial science, carried forward to the postcolonial world, where data-gathering and application happen in the colony, while theorizing happens in the metropole" (Connell 2007:ix). In the light of such a hierarchical relationship, where the researcher has an intellectual advantage over the studied individual and can assess them in advance while developing their social theory, the question arises-whose story is represented in the resulting analysis? Do not those parallel narratives of the authors and Władek talk about two different visions of the world: the one of Władek-about his life as he lived it and remembered it? And Thomas and Znaniecki's-about their founding story-tale?

The story of Władek is immersed in the matter of everyday life, in experiences, emotions, events, encounters, and decisions. The authors' tale, on the other hand, locates a peasant's story, or even "immobilizes" it, in the grid of external concepts and socio-psychologizing typologies. What they offer is the exploratory point of view, a vivisection-style narrative, or even a restrained aloof report, not allowing any true encounter with the Stranger, classifying this Other, poor peasant, in advance, according to the pre-imposed criteria. No true meeting took place here, only the use of material provided by the peasants.

Especially in the context of assurance expressed by the authors that "we must put ourselves in the position of the subject" (Thomas and Znaniecki 1919:20), such a strategy must be thought-provoking. And, going further, is "putting ourselves in the position of the subjects" equivalent with giving them a voice or offering them some form of repre- 
sentation in the discourse? Does it truly reach their vision of reality?

Admiring the scale of The Polish Peasant, the great erudition of its authors, the enormous amount of work involved, one must admit, however, that illuminating interpretations of Thomas and Znaniecki, although they talk about peasants, although they quote their written words, do not bring the true peasants' voice. They rather lose it in "the objective world of science," in the way "the scientist sees them" in their theoretical analysis (Thomas and Znaniecki 1919:21). In this sense, The Polish Peasants represented the interests, views, and voices of the students of culture.

The question remains whether and under what conditions would it be possible to overcome the dichotomy of a researcher occupying the higher position and a studied individual from the lower class? And how to avoid the asymmetry when an enlightened researcher sees oneself as a privileged one, who may show the studied ones the ways of their emancipation? Perhaps the Workers' Paper (Mothé 2013) could bring some help here, as they value the knowledge of workers, allowing them to gain higher self-awareness, and rise above the limitations of their own class. ${ }^{37}$

\footnotetext{
${ }^{37}$ Daniel Mothé describes the Workers' Paper (1955) as an effect of the self-inquiries of the workers, being "at the same time the expression of workers' experiences (and in the sense...that it can only be written by workers themselves) and the means of aiding in the theorization of this experience (and, in this way, contributing to the process of politicizing the working class). But, the paper must not separate itself from this experience, for otherwise it will necessarily escape the control of the working class" (Mothé 2013). "The collective, non-hierarchical production of knowledge, immersed in the everyday experiences of working people, does not treat them as things, objects of research, data, but as active entities gaining self-knowledge. Workers' inquiries are a manifestation of working people's autonomy, a method of learning from themselves" (Szwabowski 2019:30-31 [trans. AK]).
}

It seems that memoir competitions carried out on a large scale and addressed to such various social groups performed this task better. Certainly, the approach of Thomas and Znaniecki set the right direction here, outlined the path of research, and the way of reaching the underprivileged social strata. ${ }^{38}$ The true implementation of this idea, however, can only be observed in the mass memoir movement, in which peasants, workers, and representatives of the lowest social classes were given the floor. They allowed the memoirists' voices to break through. In their mass, they had a chance to resonate, set the tone, testify to the living conditions of their own social class. But, also, to leave a "souvenir," a memento, a lasting trace of their existence, and elusive everyday life.

\section{Conclusion}

I focused here on the social practice of creating personal documents (memoirs) and using life records (autobiographies) as forms of enacting individual agency and allowing them to speak with one's voice in the social space. For centuries, the voices of peasants and working-class were silenced as they had no access to the means which would enable them to speak and prevail in social space. The eventual representations of these groups' views were created by other, more privileged classes. We can consider such a situation in terms of the "great erasure"the phenomenon discussed by Raewyn Connell

\footnotetext{
38 Very similar postulates of researching "everyday heroes" and "nameless people" appeared in 1929 in the manifest of the French Annales School, which represented a new approach to the methodology of history. The founders of the school, Marc Bloch and Lucien Febvre, suggested breaking with the dominance of political history, and instead proposed the so-called "total history" as extensive research on former societies combining interdisciplinary research. Assuming the collective nature of human mentality, they emphasized the importance of taking into account all strata of society and, above all, "the removal of barriers between various fields of knowledge....and reaching 'silent' social groups" (Kosiński 2004:134 [trans. AK]).
} 
(2007:46) - that entails "the erasure of the experience of the majority of humankind from the foundation of social thought."

Based on that, one can see how the "memoir competitions"-a very popular research practice being introduced in Poland directly by Florian Znaniec$\mathrm{ki}$-have changed power relations in the field of generating knowledge about social reality. Znaniecki certainly understood the importance and consequences of these actions, as he claimed that he intended to reach social groups that for centuries had been "great mutes" (Znaniecki 1971:16). In this way, the collective experience of the whole generation of peasants and physical workers become recognized and represented in the discourse. The necessary condition for such an extensive collective process was the progressive literalization of Polish society. It should also be mentioned that historical changes played an important role in the entire process of the emancipation of the voices of the lower social classes. Violent social changes resulting, first, from the Nazi occupation, the extermination of Jews, and then taking power by proletariat after WWII, getting rid of the aristocracy, and communist radical reforms in the ownership structure were the significant part of this process (Leder 2014).

The memoir competitions in Poland have "become a universally recognized form of participation of the masses in the creation of lasting documentary and cultural values" (Jakubczak 1966:86 [trans. AK]). Social memoirism had many functions. For the authors, themselves, writing memoirs was an educating, socializing, and socio-cultural practice, as well as a transformative one:

People who seldom use pens to write a letter to their relatives, a peasant or a worker by starting to scratch their autobiography, which may be published in print, are transforming from a passive consumer of culture into an active creator of cultural values. It is not just about a positive...phenomenon of gaining practice in expressing their thoughts by the authors of the memoirs-more important are the internal changes taking place in the memoirist as he enters the social role of a chronicler of the history of his class. [Jakubczak 1966:87 (trans. AK)]

Asking people for their memoirs was perceived by them as ennobling. They undertook this task with great passion, and, as evidenced in their accounts, they experienced the whole process of creation as poignant. People felt grateful that they could express themselves and talk about their lives. Many memoirs have been published in extenso only with an introduction by the editor, ${ }^{39}$ so they could speak with their very substance and become part of the cultural discourses, as well as add to the knowledge shared with others. ${ }^{40}$ The institution of Polish Memoirism, that systematically gathered a huge number of autobiographies, enabled the poor and voiceless parts of society to speak and be heard not only by social researchers, but also by other members of society, as well as by themselves. In this sense, the monumental work of Thomas and Znaniecki was a trigger of the gradual process of revealing "blind spots" on the map of social reality.

\footnotetext{
39 Pamiętniki emigrantów: Francja (1939); Życiorysy górników (1949); Nowe pamiętniki chłopów (1962); Pamiętniki osadników ziem odzyskanych (1963); Miesiąc mojego życia (1964); Młode pokolenie wsi Polski Ludowej, volumes I-IX published from 1964 to 1980; Wieś polska 1939-1948 (1967); Awans społeczny robotników rolnych w Polsce Ludowej (1975); Antologia pamiętnikarstwa polskiego (1982), and many others.

${ }^{40}$ Many voices, however, are still waiting for their chance. For example, in the case of the competition for memoirs of the unemployed in 1933, out of 744 biographies, only 57 have been published (Krzywicki 1933), the rest of the handwritten materials are still waiting to be processed and digitized (Posłuszny and Kubicki 2019:99).
} 


\section{Acknowledgments}

The author would like to thank Giuseppina Cersosimo for the opportunity to participate in the con-

\section{References}

Antologia pamiętnikarstwa polskiego. Pamiętniki Polaków 1918-1978 [Anthology of Polish Memoirism. Diaries of Poles 1918-1978]. 1982. Introduction by J. Chałasiński and J. Szczepański. Edited by B. Gołębiowski, M. Grad, and F. Jakubczak. Warsaw: Ludowa Spółdzielnia Wydawnicza.

Awans społeczny robotników rolnych w Polsce Ludowej [Social Advancement of Agricultural Workers in People's Poland]. 1975. Warsaw: Instytut Wydawniczy CRZZ.

Bardach, Juliusz, Bogusław Leśnodorski, and Michał Pietrzak. 1987. Historia państwa i prawa polskiego [History of the Polish State and Law]. Warsaw: Państwowe Wydawnictwo Naukowe.

Berkan, Władysław. 1923. Życiorys własny [One’s Biography]. Poznan: Fiszer i Majewski.

Blumer, Herbert. [1969] 1998. Symbolic Interactionism. Perspective and Method. Berkeley, CA: University of California Press.

Bojko, Jakub. 1904. Dwie dusze [Two Souls]. Cracow: "Przyjaciel Ludu."

Budzyński, Andrzej. 1993. “Sytuacja bytowa społeczeństwa w badaniach Instytutu Gospodarstwa Społecznego w latach 1920-1944 [The Living Situation of Society in the Research of the Institute of Social Economy in 1920-1944]." Biuletyn IGS 3-4:84-94.

Budzyński, Andrzej. 1997. "Pamiętnikarstwo jako metoda badania rzeczywistości społecznej [Diaries as a Method of Researching Social Reality]." Biuletyn IGS 1-4:147-171.

Budzyński, Andrzej, ed. 2003. Pamiętniki bezrobotnych. Materiaty konkursowe. Prace nagrodzone, tom 1 [Diaries of the Unemployed. Competition Materials. Award-Winning Works, volume 1]. Warsaw: Oficyna Wydawnicza SGH. ference "The Polish Peasant in Europe and America 1918-1920" held in Salerno in 2019. She is also grateful to the Reviewers of the text for their invaluable comments.

Burr, Anna Robeson. 1909. The Autobiography: A Critical and Comparative Study. Boston: Houghton Mifflin.

Cersosimo, Giuseppina. 2020. "The Polish Peasant in Europe and America. Some Remarks after One Hundred Years." Italian Sociological Review 10(2S):329-340.

Chałasiński, Józef. 1931. “Autobiografia jako źródło badań nad zachowaniem społecznym [Autobiography as a Source of Research on Social Behavior]." Oświata i Wychowanie 4:302-328.

Chałasiński, Józef. 1971. “Dokumentalno-kulturowe wartości pamiętnikarstwa ludowego. [Documentary and Cultural Values of Folk Memoirism]." Pp. 21-25 in Pót wieku pamiętnikarstwa [Half a Century of Memoirism], edited by S. Adamczyk, S. Dyksiński, and F. Jakubczak. Warsaw: Ludowa Spółdzielnia Wydawnicza.

Chałasiński, Józef. 1972. "Pierwsi pamiętnikarze plebejscy [The First Plebeian Memoirists]." Pp. 18-24 in Ruch pamiętnikarski i przemiany polskiej kultury [The Memoirism Movement and Changes in Polish Culture], edited by B. Gołębiowski, J. Kossak, and K. Krzemień. Warsaw: PWN.

Chałasiński, Józef. 1974. "Pamiętniki a więź z rzeczywistością Polski [Memoirs and the Bond with the Reality of Poland]." Pamiętnikarstwo Polskie (1-2):23-30.

Chałasiński, Józef. [1931] 1979. Drogi awansu społecznego robotnika. Studium oparte na autobiografiach robotników [The Paths of Social Promotion of the Worker. A Study Based on the Autobiographies of Workers]. Warsaw: Ludowa Spółdzielnia Wydawnicza.

Chałasiński, Józef. 1982. “Pamiętnikarstwo jako świadectwo przeobrażeń narodu polskiego [Memoirs as a Testimony to the Transformations of the Polish Nation]." Pp. 9-29 in Pamiętniki Polaków 1918-1978. Antologia pamiętnikarstwa polskiego, t. 1. Dru- 
ga Rzeczypospolita 1918-1939 [Diaries of Poles 1918-1978. Anthology of Polish Memoirism, vol. 1. The Second Republic of Poland 19181939], edited by B. Gołębiowski, M. Grad, and F. Jakubczak. Warsaw: Ludowa Spółdzielnia Wydawnicza.

Chałasiński, Józef. [1938] 1984. Młode pokolenie chłopów. Procesy $i$ zagadnienia ksztattowania sie warstwy chłopskiej w Polsce [The Young Generation of Peasants. Processes and Issues of Shaping the Peasant Class in Poland]. Warsaw: Ludowa Spółdzielnia Wydawnicza.

Cieński, Andrzej. 1975. "Kryteria oceny prozy pamiętnikarskiej [Criteria for the Evaluation of Diaries' Prose]." Pamiętnik Literacki 66(2):17-36.

Cieński, Andrzej. 1981. Pamiętnikarstwo polskie XVIII wieku [Polish Memoirism of the 18th Century]. Wroclaw: Zakład Narodowy im. Ossolińskich.

Connell, Raewyn. 2007. Southern Theory. The Global Dynamics of Knowledge in Social Science. Cambridge: Polity Press.

Coser, Lewis A. 1977. Masters of Sociological Thought: Ideas of Historical and Social Context. New York: Harcourt Brace Jovanovich.

Czyżewski, Marek. 1992. “Uwagi o badaniach biograficznych [Notes on Biographical Research]." Pp. 93-100 in Bunty i stużebność uczonego: profesor Józef Chałasiński [Rebellions and Servitude of the Scientist: Professor Józef Chałasiński], edited by L. Wojtczak. Lodz: Wydawnictwo Uniwersytetu Łódzkiego.

Deczyński, Kazimierz. 1907. Żywot chłopa polskiego na początku XIX wieku [The Life of a Polish Peasant at the Beginning of the 19th Century]. Warsaw: G. Centnerszwer i Ska.

Doliński, Wojciech. 2012. Nowe ślady - stare drogi. Europa w pamiętnikach Polaków [New Traces-Old Roads. Europe in Poles' Diaries]. Cracow: Zakład Wydawniczy Nomos.

Dulczewski, Zygmunt. 1992. Florian Znaniecki. Life and Work. Poznan: Wydawnictwo Nakom.

Dulczewski, Zygmunt. 1975. “Florian Znaniecki jako twórca metody autobiograficznej w socjologii [Florian Znaniecki as the Founder of the Autobiographical Method in Sociology ]." Pp. 75-88 in Florian Znaniecki i jego rola w socjologii [Florian Znaniecki and His Role in Sociology], edited by A. Kwilecki. Poznan: Wydawnictwo Naukowe UAM.

Dunin-Wąsowicz, Krzysztof. 1974. "Pamiętnikarstwo Polskie [Polish Memoirism]." Dzieje Najnowsze 6(1):199-206.
Freire, Paulo and Donaldo Macedo. 2005. Literacy. Reading the Word and the World. London: Routledge.

Garczyński, Stefan. 1751. Anatomia Rzeczypospolitej Polskiej [Anatomy of the Republic of Poland]. Warsaw: Drukarnia Jezuitów.

Gluza, Zbigniew. 2012. "Archiwa Ośrodka KARTA [Archives of the KARTA Center]." Pp. 27-35 in Archiwistyka Społeczna [Social Archivistics], edited by K. Ziętal. Warsaw: Ośrodek KARTA.

Gołębiowski, Bronisław. 1977. Dynamika aspiracji. Studium przemian świadomości społecznej młodzieży polskiej w latach 19451975 [The Dynamics of Aspirations. A Study of Changes in Social Awareness of Polish Youth in 1945-1975]. Warsaw: Spółdzielnia Wydawniczo-Handlowa "Książka i Wiedza."

Gołębiowski, Bronisław and Zdzisław Grzelak. 1971. “O strukturze treści 169 wypowiedzi autobiograficznych 'Moje pierwsze kroki w gospodarstwie' [On the Structure of the Content of 169 Autobiographical Accounts 'My First Steps on the Farm']." Przeglad Socjologiczny 24:193-227.

Grabski, Władysław. 1936. "Pamiętniki chłopów i środowisko wsi polskiej [Peasants' Memoirs and the Environment of the Polish Countryside]." Przeglad Socjologiczny 4(3-4):297-340.

Grabski, Władysław. 1938. “Wpływ ustroju agrarnego folwarcznego na życie społeczne wsi [The Influence of the Agrarian Manor System on the Social Life of the Village]." Roczniki Socjologii Wsi 3:1-53.

Handelsman, Marceli. 1907a. “Kazimierz Deczyński i jego pamiętnik [Kazimierz Deczyński and His Memoir]." Pp. 24-51 in Żywot chłopa polskiego na poczatku XIX wieku [The Life of a Polish Peasant at the Beginning of the $19^{\text {th }}$ Century], edited by K. Deczyński. Warsaw: G. Centnerszwer i Ska.

Handelsman, Marceli. 1907b. “Ewolucja włościańska w Królestwie Polskim w pierwszej ćwierci XIX w. [Peasant Evolution in the Kingdom of Poland in the First Quarter of the 19th Century]." Pp. 1-23 in Żywot chłopa polskiego na początku XIX wieku [The Life of a Polish Peasant at the Beginning of the $19^{\text {th }}$ Century], edited by K. Deczyński. Warsaw: G. Centnerszwer i Ska.

Hordyński, Zdzisław. 1883. O Towarzystwie Szubrawców [About the Rascal Society]. Lvov: Drukarnia Władysława Łozińskiego.

Jakubczak, Franciszek. 1966. Konkursy na pamiętniki w Polsce, 1921-1966 [Contests for Diaries in Poland, 1921-1966]. Warsaw: Komitet Badań nad Kulturą Współczesną Polskiej Akademii Nauk. 
Jakubczak, Franciszek. 1968. “Pół wieku badań nad rodziną chłopską w Polsce [Half a Century of the Research on the Peasant Family in Poland]." Przeglad Socjologiczny 22(2):106-129.

Kaźmierska, Kaja. 2012. Biography and Memory: The Generational Experience of the Shoah Survivors. Boston: Academic Studies Press.

Konecki, Krzysztof. 2017. "Qualitative Sociology." Pp. 143152 in The Cambridge Handbook of Sociology. Volume 1. Core Areas in Sociology and the Development of the Discipline, edited by K. O. Korgen. Cambridge: Cambridge University Press.

Konopczyński, Władysław. 1966. Polscy pisarze polityczni XVIII w. [Polish Political Writers of the 18th Century]. Warsaw: Państwowe Wydawnictwo Naukowe.

Kosiński, Krzysztof. 2004. "Pamiętnikarstwo konkursowe jako źródło historyczne [Competition Memoirism as a Historical Source]." Polska 1944/45-1989. Studia i Materiaty 6:133-145.

Koźmian, Andrzej E. 1843. O kmiotku polskim [About the Polish Yokel]. Leszno: E. Günther.

Kraśko, Nina. 1996. Instytucjonalizacja socjologii w Polsce 19201970 [Institutionalization of Sociology in Poland 1920-1970]. Warsaw: Wydawnictwo Naukowe PWN.

Krzywicki, Ludwik, ed. 1933. Pamiętniki bezrobotnych [The Memoirs of the Unemployed]. Warsaw: Instytut Gospodarstwa Społecznego.

Krzywy, Roman. 2012. Silva Rerum. O staropolskich pamiętnikach [Silva Rerum. About Old Polish Diaries]. Retrieved June 21, 2019 (https:// www.wilanow-palac.pl/o_staropolskich_pamietnikach.html).

Kuciel-Frydryszak, Joanna. 2018. Stużace do wszystkiego [The Help for Doing Everything]. Warsaw: Wydawnictwo Marginesy.

Kwilecki, Andrzej. 2011. "Pionierskie przedsięwzięcia badawcze poznańskiej socjologii 1921-1922. Konkurs na życiorys własny pracownika fizycznego [Pioneering Research Undertakings of Poznan Sociology 1921-1922. A Competition for a Biography of a Hand Worker]." Ruch Prawniczy, Ekonomiczny i Socjologiczny 73(2):323-331.

Lachnicki, Ignacy. 1815. Biografia włościanina nad brzegami Niemna, powyżej Łosośnej mieszkajacego [Biography of the Peasant on the Banks of the Niemen, Living Above Lososna]. Warsaw: Drukarnia Wiktora Dąbrowskiego.

Lebow, Katherine. 2014. "Autobiography as Complaint: Polish Social Memoir between the World Wars." Laboratorium 6(3):13-26.
Leder, Andrzej. 2014. Prześniona rewolucja. Ćwiczenie z logiki historycznej [Overdreamed Revolution. An Exercise in Historical Logic]. Warsaw: Wydawnictwo Krytyki Politycznej.

Łepkowski, Tadeusz. 1973. Stownik historii Polski [Dictionary of Polish History]. Warsaw: Wiedza Powszechna.

Łuba, Joanna. 2019. “Wydobywanie człowieka z historii: Archiwum Ośrodka KARTA [Extracting Man from History: Archives of the KARTA Center]." Kultura i Społeczeństwo 62(1):105-112.

Madejska, Marta. 2018. Aleja Włókniarek [Female Textile Workers Alley]. Wolowiec: Wydawnictwo Czarne.

Maliszewski, Edward. 1928. Bibliografia pamiętników polskich i Polski dotyczacych (druki i rękopisy) [Bibliography of Polish and Concerning Poland Memoirs (Hard Copies and Manuscripts)]. Warsaw: Towarzystwo Miłośników Historii.

Marchlewski, Julian Baltazar. 1903. Stosunki społeczno-ekonomiczne w Ziemiach Polskich Zaboru Pruskiego [Socio-Economic Relations in the Polish Lands of the Prussian Partition]. Lvov: Polskie Towarzystwo Nakładowe.

Miesiac mojego życia: wybór pamiętników z konkursu polskiego radia i tygodnika kulturalnego [A Month of My Life: Selection of Diaries from the Competition of the Polish Radio and the Cultural Weekly]. 1964. Introduction by J. Chałasiński. Edited by E. Jagiełło-Łysiowa and L. Sobierajski. Warsaw: Ludowa Spółdzielnia Wydawnicza.

Miller, Herbert A. and Robert E. Park [and William I. Thomas]. 1921. Old World Traits Transplanted. New York: Henry Holt.

Młode pokolenie wsi Polski Ludowej. Pamiętniki i studia [The Young Generation of the Villages of People's Poland. Memoirs and Studies], edited by J. Chałasiński. 1964-1980. Warsaw: Ludowa Spółdzielnia Wydawnicza. Vol. I. Awans pokolenia [Generation Advancement]. 1964; Vol. II. Tu jest mój dom. Pamiętnik z Ziem Zachodnich i Pótnocnych [Here Is My Home. A Memoir from the Western and Northern Lands]. 1965; Vol. III. W poszukiwaniu drogi - Pamiętniki działaczy [In Search of the Way-Activists' Memoirs]. 1966; Vol. IV. Od chtopa do rolnika [From a Peasant to a Farmer]. 1967; Vol. V. Gospodarstwo i rodzina [Farm and Family]. 1969; Vol. VI. Nauczyciele i uczniowie [Teachers and Students]. 1968; Vol. VII. Nowe zawody [New Professions]. 1969; Vol. VIII. Drogi awansu w mieście [Ways of Promotion in the City]. 1972; Vol. IX. Odzyskanie młodości [Regaining Youth]. 1980.

Mothé, Daniel. 2013. “The Problem of the Workers' Paper (1955)" The Viewpoint Magazine 3: Workers' Inquiry, September. Retrieved October 15, 2020 (https://www.viewpointmag. com/2013/09/26/the-problem-of-the-workers-paper/). 
Nowe pamiętniki chłopów [New Memoirs of Peasants]. 1962. Edited by F. Jakubczak. Warsaw: Książka i Wiedza.

O chłopach [Of Peasants]. 1847. Leipzig: Księgarnia Zagraniczna.

Palska, Hanna. 1997. “Polskie pamiętnikarstwo konkursowe: ideologia w autobiografii, autobiografia w ideologii [The Polish Contest Memoirs. Ideology in Autobiography, Autobiography in Ideology]." ASK 1-2(5-6):9-17.

Palska, Hanna. 1998. “'Beznadziejny proletariusz' w pamiętnikach. Kilka uwag o niektórych kulturowych uwarunkowaniach nowej biedy ['Hopeless Proletarian' in Diaries. Remarks on Some of the Cultural Determinants of the New Poverty]." Kultura i Społeczeństwo 42(2):105-118.

Pamiętnikarstwo Polskie [Polish Memoirism]. 1971. 1(1).

Pamiętniki emigrantów: Francja [Memoirs of Emigrants: France]. 1939. Warsaw: Instytut Gospodarstwa Społecznego.

Pamiętniki osadników ziem odzyskanych [Diaries of the Settlers of Regained Territories]. 1963. Edited by Z. Dulczewski and A. Kwilecki. Poznan: Wydawnictwo Poznańskie.

Pasek, Jan Chryzostom. [1836] 1979. The Memoirs of Jan Chryzostom $z$ Goslawic Pasek. New York: The Kosciuszko Foundation.

Pawłowska, Kinga. 2015. "Kobieta wiejska w pamiętnikach chłopów z lat 30. XX wieku [A Country Woman in Peasants' Diaries from the 1930s]." Wieś i Rolnictwo 166.2(1.2):51-65.

Pietraszek, Edward. 1985. "Polski robotnik między Polską a Europą (W stulecie urodzin Jakuba Wojciechowskiego) [Polish Worker between Poland and Europe (On the 100th Birthday of Jakub Wojciechowski)]." Studia Socjologiczne 2:173-194.

Posłuszny, Łukasz and Paweł Kubicki. 2019. "Pamiętniki bezrobotnych w zbiorach Instytutu Gospodarstwa Społecznego: historia, charakterystyka i potencjał badawczy [Diaries of the Unemployed in the Collection of the Institute of Social Economy: History, Characteristics, and Research Potential]." Kultura i Społeczeństwo 62(1):95-104.

Praczyk, Małgorzata. 2018. Pamięć środowiskowa we wspomnieniach osadników na "Ziemiach Odzyskanych" [Environmental Memory in the Memoirs of Polish Settlers in the 'Recovered Territories']. Poznan: Wydawnictwo Instytutu Historii UAM.

Rauszer, Michał. 2020. Bękarty pańszczyzny. Historia buntów chtopskich [Serfdom Bastards. The History of Peasant Revolts]. Warsaw: Wydawnictwo RM.
Reymont, Ladislas S. 1925. The Peasants [Chtopi]. London: Jarrolds Publishers.

Rokuszewska-Pawełek, Alicja. 2002. Chaos i przymus. Trajektorie wojenne Polaków - analiza biograficzna [Chaos and Constraint. War Trajectories of Poles-Biographical Analysis]. Lodz: Wydawnictwo Uniwersytetu Łódzkiego.

Rura, Przemysław. 2019. "Style życia bezrobotnych w drugiej Rzeczypospolitej: charakterystyka na podstawie pamiętników nadesłanych na konkurs 'Życiorysy bezrobotnych' w 1938 roku [Lifestyles of the Unemployed in the Second Republic of Poland: Characteristics Based on the Diaries Submitted for the 'Biographies of the Unemployed' Competition in 1938]." Kultura i Społeczeństwo 63(1):69-82.

Rytel, Jadwiga. 1962. "Pamiętniki" Paska na tle pamiętnikarstwa staropolskiego. Szkic z dziejów prozy narracyjnej [Pasek's "Memoirs" against the Background of Old Polish Memoirism. A Sketch from the History of Narrative Prose]. Wroclaw, Warsaw, Cracow: Zakład Narodowy im. Ossolińskich, Wydawnictwo Polskiej Akademii Nauk.

Sajkowski, Alojzy. 1964. Nad staropolskimi pamiętnikami [About Old Polish Diaries]. Poznan: Uniwersytet im. Adama Mickiewicza.

Sitek, Wojciech. 2002. “Florian Znaniecki." Pp. 363-371 in Encyklopedia socjologii, t. 4 [Encyclopedia of Sociology, vol. 4], edited by Z. Bokszański et al. Warsaw: Oficyna Naukowa.

Staszic, Stanisław. 1790. Przestrogi dla Polski z teraźniejszych politycznych Europy zwiąków i z praw natury wypadajace [Warnings for Poland from Present-Day Political Relations in Europe and from the Laws of Nature]. Warsaw: Wydawnictwo Michał Gröll.

Sułek, Antoni. 2007. “The Marienthal 1931/1932 Study and Contemporary Studies on Unemployment in Poland." Polish Sociological Review 157(1):3-26.

Szarota, Tomasz. 1978. “Niemcy w oczach Polaków podczas II wojny światowej [Germans in the Eyes of Poles during World War II]." Dzieje Najnowsze 10(2):143-175.

Szczepański, Jan. 1976. “Dzieło W. I. Thomasa i F. Znanieckiego $\mathrm{w}$ rozwoju socjologii [The Work of W. I. Thomas and F. Znaniecki in the Development of Sociology]." Pp. 30-38 in Chłop polski w Europie i w Ameryce. Tom I. Organizacja grupy pierwotnej [The Polish Peasant in Europe and America. Volume I. Primary-Group Organization] by W. I. Thomas and F. Znaniecki. Warsaw: Ludowa Spółdzielnia Wydawnicza. 
Szwabowski, Oskar. 2019. Nekrofilna produkcja akademicka i pieśni partyzantów. Autoetnografia pracy akademickiej i dydaktycznej w czasach zombie-kapitalizmu [Necrophilic Academic Production and Partisan Songs. Autoethnography of Academic and Didactic Work in the times of Zombie-Capitalism]. Wroclaw: Instytut Pedagogiki Uniwersytetu Wrocławskiego.

Śreniowski, Stanisław. [1948] 1997. Zbiegostwo chłopów w dawnej Polsce jako zagadnienie ustroju społecznego [Confluence of Peasants in Old Poland as an Issue of Social System]. Lodz: Wydawnictwo Uniwersytetu Łódzkiego.

Thomas, William I. 1905. "The Province of Social Psychology." American Journal of Sociology 10(4):445-455.

Thomas, William I. 1912. "Race Psychology: Standpoint and Questionnaire, with Particular Reference to the Immigrant and the Negro." American Journal of Sociology 17:725-775.

Thomas, William I. and Florian Znaniecki. 1918. Polish Peasant in Europe and America. Monograph of an Immigrant Group. Volume 1: Primary-Group Organization. Chicago: University of Chicago Press.

Thomas, William I. and Florian Znaniecki. 1918. Polish Peasant in Europe and America. Monograph of an Immigrant Group. Volume 2: Primary-Group Organization. Chicago: University of Chicago Press.

Thomas, William I. and Florian Znaniecki. 1919. Polish Peasant in Europe and America. Monograph of an Immigrant Group. Volume 3: Life Record of an Immigrant. Boston: Richard G. Badger, Gorham Press.

Thomas, William I. and Florian Znaniecki. 1920. Polish Peasant in Europe and America. Monograph of an Immigrant Group. Volume 5: Organization and Disorganization in America. Boston: Richard G. Badger.

Tomasson, Richard F. 1975. "The Literacy of the Icelanders." Scandinavian Studies 47(1):66-93.

Urbaniak-Kopeć, Alicja. 2018. Anioł w domu, mrówka w fabryce [Angel in the House, Ant in the Factory]. Warsaw: Wydawnictwo Krytyki Politycznej.

Wieś polska, 1939-1948 [A Polish Village, 1939-1948]. 1967. Edited by K. Kersten and T. Szarota. Warsaw: Państwowe Wydawnictwo Naukowe.
Wincławski, Włodzimierz. 2012. “Wstęp do socjologii Floriana Znanieckiego - wyzwanie rzucone polskiej socjologii i jego następstwa (dziewięćdziesiąta rocznica publikacji dzieła) [Introduction to Florian Znaniecki's Sociology-The Challenge to Polish Sociology and Its Consequences (90th Anniversary of the Publication of the Work)]." Roczniki Historii Socjologii 2:5-18.

Winnicka, Halina. 1972. Wizerunki oświeconych [Images of the Enlightened]. Warsaw: Państwowe Zakłady Wydawnictw Szkolnych

Wiśniewski, Antoni. 1760. Rozmowy w ciekawych y potrzebnych filozoficznych y politycznych materyach. T. 1 [Conversations in Interesting and Necessary Philosophical and Political Matters. Vol. 1]. Warsaw: Drukarnia Pijarów.

Wojciechowski, Jakub. [1930] 1971. Życiorys własny robotnika [The Worker's Biography]. Edited by J. Chałasiński. Poznan: J. Jachowski.

[Znaniecki, Florian]. 1920. "Intellectual America by a European." The Atlantic Monthly. A Magazine of Literature, Science, Art and Politics, Boston, February:188-199.

Znaniecki, Florian. 1931. Miasto w świadomości jego obywateli [The City in View of Its Inhabitants]. Poznan: Polski Instytut Socjologiczny.

Znaniecki, Florian. 1963. Cultural Sciences: Their Origin and Development. Urbana, IL: University of Illinois Press.

Znaniecki, Florian. 1971. Nauki o kulturze [Cultural Sciences. Their Origin and Development]. Warsaw: PWN.

Znaniecki, Florian. [1923] 1976. "Autobiografia jako materiał do badań socjologicznych [Autobiography as a Material for Sociological Research]." Przeglad Socjologiczny 28:154-166.

Znaniecki, Florian. 1978. “Intelektualna Ameryka - napisał Europejczyk [Intellectual America by a European]." Kultura i Społeczeństwo 22(4):33-46.

Znaniecki, Florian. [1922] 1988. Wstęp do socjologii [Introduction to Sociology]. Warsaw: Gebethner \& Wolf.

Życiorysy górników [Biographies of Miners]. 1949. Katowice: Wydawnictwo Związku Zawodowego.

\section{Citation}

Kacperczyk, Anna. 2020. “Revealing the Silenced Spots: The Influence of Thomas and Znaniecki on the Study of Marginalized Aspects of Social Life." Qualitative Sociology Review 16(4):212-247. Retrieved Month, Year (http://www.qualitativesociologyreview. org/ENG/archive_eng.php). DOI: http://dx.doi.org/10.18778/1733-8077.16.4.13 